UNIVERSIDADE FEDERAL DE JUIZ DE FORA

FACULDADE DE CIËNCIAS ECONÖMICAS

CAIO CEZAR FERNANDES

EFEITO DA INTERNET SOBRE O COMÉRCIO INTERNACIONAL

JUIZ DE FORA - MG 
Dissertação apresentada ao Programa de PósGraduação em Economia da Faculdade de Economia da Universidade Federal de Juiz de Fora, como parte integrante do relatório parcial das atividades de mestrado.

Área de concentração: Economia Regional e Macroeconomia

Orientador: Prof. Dr. Admir A. Betarelli Junior

Coorientador: Prof. Dr. Weslem Rodrigues Faria. 
Ficha catalográfica elaborada através do programa de geração automática da Biblioteca Universitária da UFJF, com os dados fornecidos pelo (a) autor (a)

Cezar Fernandes, Caio.

Efeito da Internet sobre o comércio internacional / Caio Cezar Fernandes. -- 2021.

$76 \mathrm{p}$.

Orientador: Admir Antonio Betarelli Junior Coorientador: Weslem Rodrigues Faria Dissertação (mestrado acadêmico) - Universidade Federal de Juiz de Fora, Faculdade de Economia. Programa de Pós-Graduação em Economia, 2021.

1. Modelo gravitacional. 2. Comércio internacional. 3. Internet. 4. Tecnologia da Informação e Comunicação. I. Antonio Betarelli Junior, Admir, orient. II. Rodrigues Faria, Weslem, coorient. III. Título. 


\section{EFEITO DA INTERNET SOBRE O COMÉRCIO INTERNACIONAL}

Dissertação apresentada ao Programa de PósGraduação em Economia da Faculdade de Economia da Universidade Federal de Juiz de Fora, como requisito parcial a obtenção do título de Mestre em Economia Aplicada. Área de concentração: Economia Regional e Macroeconomia

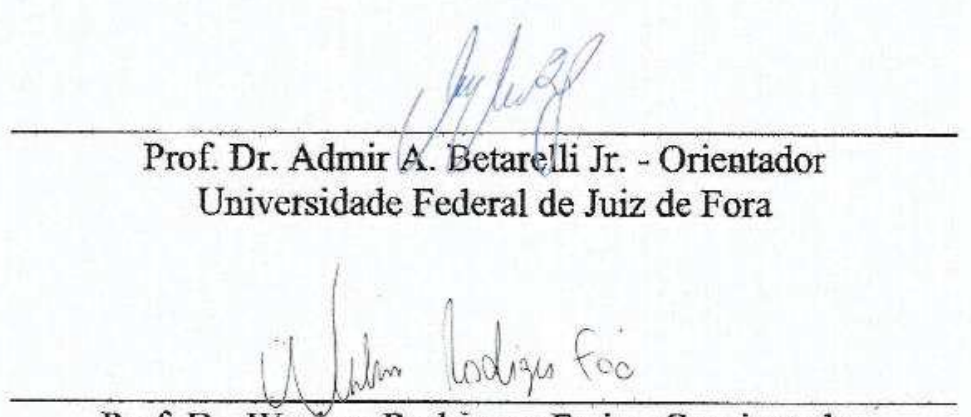

Prof. Dr. Weslem Rodrigues Faria - Coorientador Universidade Federal de Juiz de Fora

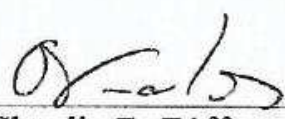

Prof. Dr. Claudio R. Fóffano Vasconcelos

Universidade Federal de Juiz de Fora 


\section{AGRADECIMENTOS}

Agradeço, primeiramente, à Deus, pelo dom da vida e pela proteção aos meus familiares e amigos.

Agradeço aos meus pais, Claudinéia e Adão, e aos meus avós, Maria e Vitor, pelo apoio em todas as jornadas da minha vida, desde pequeno até os dias de hoje. Sem vocês, nada disso seria possível. Agradecer a minha irmã Camila, por sempre seguir na mesma caminhada e por me apoiar em todas as batalhas.

Agradecer a minha grande companheira e amiga que a vida me proporcionou, Flaviana, por me trazer amor, afeto, dedicação, paz e conforto e fazer com que eu seja uma pessoa melhor a cada dia que passa. Você é uma pessoa muito especial para mim e quero continuar ao seu lado até o fim.

Aos meus amigos do lendário grupo Bate Papo UOL, Beatriz, Daniel, Heloísa, João, João Vitor, Lucas, Marina, Alex, Cláudio e Matheus, que fizeram a pós-graduação um lugar melhor, onde compartilhamos nossas conquistas e frustrações. A união da nossa turma tornou o desafio mais leve e agradável de superar. Obrigado por todos os momentos que compartilhamos juntos.

A todos os alunos que faziam parte da salinha da pós graduação, pelos momentos de risada, de estudo, de coffee break e de indignações comuns. Essa parte do mestrado foi especial.

As grandes amigas que criei na graduação e levo para a vida, Letícia e Isabela, por todos os momentos que vivemos juntos, de alegrias e tristezas.

Agradecer ao grupo R.H.T, dos grandes amigos Arthur, Bernardo, Douglas, Igor, Jhon, Marco Túlio e Norberto, por seguir mantendo a nossa amizade viva durante todo esse período, compartilhando nossas frustrações e conquistas, com intuito de sempre buscar o melhor ao próximo.

Agradecer aos meus orientadores, prof. Admir e prof. Weslem, por me motivarem a cada reunião e acreditarem no meu trabalho. O auxílio prestado por vocês foi de magnífica significância, pois o conhecimento de ambos é algo motivador e digno de elogios. A orientação ao longo do mestrado desenvolveu minhas técnicas e a qualidade das minhas produções.

Aos professores e funcionários do programa de Pós-Graduação em Economia e Faculdade de Economia da UFJF, pelos ensinamentos e contribuições ao meu trabalho; e as agências de apoio à pesquisa CAPES e UFJF, pelo apoio financeiro.

A todos os outros não mencionados nesse espaço, que foram importantes para mim nesses anos. 


\section{RESUMO}

As transformações no comércio internacional geraram uma maior integração produtiva e comercial entre países, inclusão de economias em nichos de mercados especializados, ampliação da escala de produção, economias de escala de empresas internacionais e fragmentação das cadeias de suplementos ou de insumos intermediários. Dentro desse panorama, o surgimento da Internet a partir da década de 90, junto com a propagação da globalização, propulsionaram a disseminação das TICs (Tecnologia da Informação e Comunicação) nos setores e nações, que podem proporcionar maior fluxo de informações com intuito de interromper barreiras de entrada ao mercado, com a diminuição dos custos atrelados ao comércio. O objetivo principal desse trabalho é analisar o efeito da Internet no comércio internacional levando em conta um grupo de países em distintos estágios de desenvolvimento, para o período de 2000 à 2016. Mais especificamente, este estudo aborda a penetração da Internet como instrumento de diminuição das barreiras comerciais, juntamente com a evolução tecnológica das telecomunicações. A hipótese é que a penetração da Internet, juntamente com a evolução tecnológica das telecomunicações, influenciou positivamente no fluxo do comércio, diminuindo o efeito das barreiras comerciais entre países, sejam elas referentes a distância linguística, cultural ou informacional. Os resultados apontam que, para o fluxo comercial agregado estimado via PPML, ao dobrar as redes de assinatura de banda larga entre pares de países, ceteris paribus, ocasionaria o aumento de $0,70 \%$ no fluxo comercial entre eles. Para o setor primário, o mesmo choque acarretaria o aumento de 5,30\% do fluxo comercial. A ampliação das redes de banda larga não depende de nenhum tipo de relação histórica ou política entre países, sendo necessário apenas a disposição do país em expandir suas redes de Internet. O ganho de comércio evidenciado no choque aponta um possível instrumento para países dependentes das exportações de bens pertencentes ao setor primário (de sua maioria bens homogêneos). A distância geográfica, proxy para todos os custos comerciais, entrega evidências nas quais incidem efeitos menores nos fluxos comerciais de bens manufaturados, graças a adoção tecnológica e a fragmentação produtiva, quando comparados com grandes setores da agricultura, energia e mineração, intensivos em bens homogêneos.

Palavras-chave: Modelo gravitacional; Comércio Internacional; Internet; Tecnologia da Informação e Comunicação. 


\begin{abstract}
The transformations in international trade have generated greater productive and commercial integration between countries, inclusion of economies in specialized market niches, expansion of the scale of production, economies of scale for international companies and fragmentation of the chains of supplements or intermediate inputs. Within this scenario, the emergence of the Internet from the $90 \mathrm{~s}$, together with the spread of globalization, propelled the spread of ICTs in sectors and nations, which can provide a greater flow of information to interrupt barriers to entry to the market, with decrease in costs linked to trade. This research is aimed at contributing to this gap by examining the effect of the Internet in international trade considering a group of countries in different stages of development, for the period from 2000 to 2016. More specifically, this study addresses the penetration of the Internet as an instrument to reduce trade barriers, along with the technological evolution of telecommunications. The hypothesis is that the penetration of the Internet, together with the technological evolution of telecommunications, positively influences the trade flows, reducing the effect of trade barriers between countries, whether related to linguistic, cultural or informational distance. The main findings revealed that for the aggregate trade flows estimated via PPML, when doubling as broadband subscription networks between pairs of countries, ceteris paribus, would cause an increase of $0.70 \%$ in the trade flows between them. For the primary sector, the same shock would result in an increase of $5.30 \%$ in the trade flows. Shocks in relation to the expansion of broadband networks are not dependent on any type of historical or political relationship between countries, requiring only the country's willingness to expand its Internet networks. The trade gain evidenced in the shock points to a possible instrument for countries dependent on exports of goods belonging to the primary sector (mostly homogeneous goods). Geographical distance, a proxy for all trade costs, delivers evidence that has lesser effects on the trade flows of manufactured goods, thanks to technological adoption and productive fragmentation, when compared to large sectors of agriculture, energy and mining, intensive in homogeneous goods.
\end{abstract}

Keywords: Gravity model; International Trade; Internet; Information and Communication Technology. 


\section{LISTA DE TABELAS}

TABELA 1 - Estatísticas descritivas das variáveis quantitativas do banco de dados (2000-2016)

TABELA 2 - Resultados estimados do modelo gravitacional para diferentes métodos de estimação (2000-2016) 54

TABELA 3 - Resultados estimados do modelo gravitacional para diferentes métodos de estimação, considerando intervalo temporal de quatro anos (2000-2016) 56

TABELA 4 - Resultados estimados por PPML para o modelo gravitacional considerando a divisão entre setor primário e secundário (2000-2016) 59

TABELA 5 - Resultados estimados por PPML do modelo gravitacional para os grandes setores da economia, considerando intervalo temporal de quatro anos (2000-2016) 62 


\section{LISTA DE QUADROS}

QUADRO 1 - Resumo das aplicações das TIC para o comércio internacional........................36

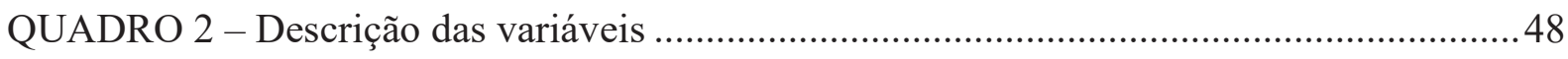




\section{LISTA DE ABREVIATURAS E SIGLAS}

2SLS - Mínimos Quadrados Generalizados de Dois Estágios

APEC - Cooperação Econômica Ásia-Pacífico

BACI - Base Analytique du Commerce Internacional

CEPII - Centre d'Etudes Prospectives et d'Informations

CES - Constant Elasticity of Substitution

CGV - Cadeias Globais de Valor

CIF - Cost, Insurance and Freight

EMBRATEL - Empresa Brasileira de Telecomunicações

FOB - Free On Board

FTA - Acordo de Facilitação de Comércio

GATT - Acordo Geral de Tarifas e Comércio

GMM - Método dos Momentos Generalizados

IED - Investimento Estrangeiro Direto

IMT - International Mobile Telecommunications

ITPD-E - International Trade and Production Database for Estimation

ITU -International Telecommunications Union

MENA - Oriente Médio e Norte da África

MQO - Mínimos Quadrados Ordinários

MRT - Termos de Resistência Multilateral

OCDE - Organização para a Cooperação e Desenvolvimento

OMC - Organização Mundial do Comércio

ONU - Organização das Nações Unidas

P\&D - Pesquisa e Desenvolvimento

PIB - Produto Interno Bruto

PPML - Poisson-Pseudo Maximun Likelihood

RESET - Regression Specification Error Test

SCM - Supply Chain Management

TELEBRÁS - Telecomunicações Brasileiras S.A.

TIC - Tecnologia da Informação e Comunicação

WDI - World Development Indicators 


\section{SUMÁRIO}

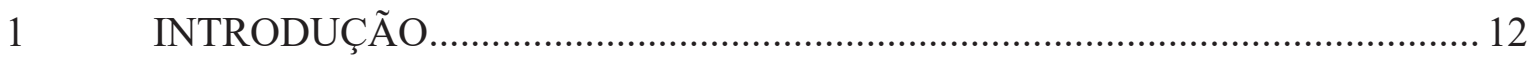

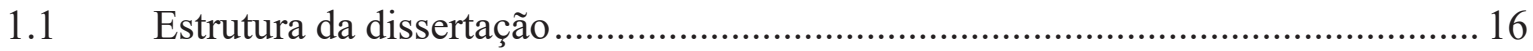

2 COMÉRCIO INTERNACIONAL E INFORMAÇÃO ........................................ 17

2.1 As tecnologias da informação e da comunicação (TIC) nas economias mundiais 17

2.2 Efeitos da TIC no comércio internacional - revisão de enfoques ..........................29

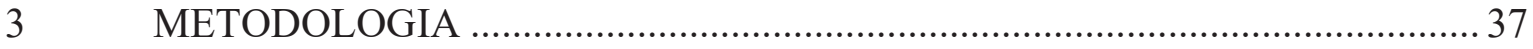

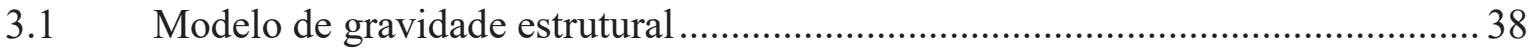

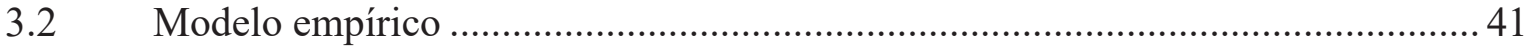

3.2.1 Fluxos comerciais nulos e heterocedasticidade ................................................... 42

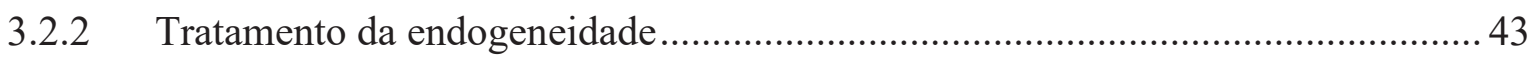

3.2.3 Termos de resistência multilateral e erro de especificação .................................... 44

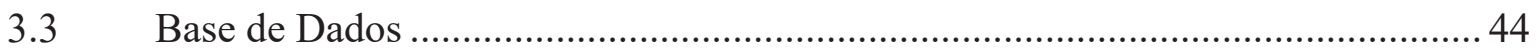

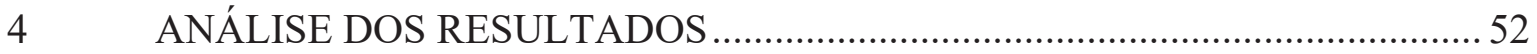

4.1 Efeitos estimados sobre o fluxo geral de comércio exterior ................................52

4.2 Efeitos estimados sobre o fluxo setorial de comércio exterior...............................6 60

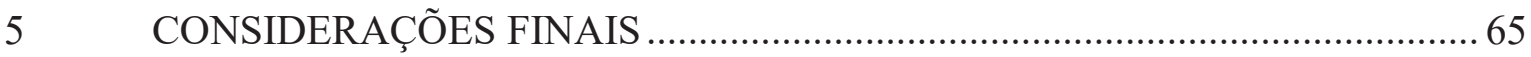

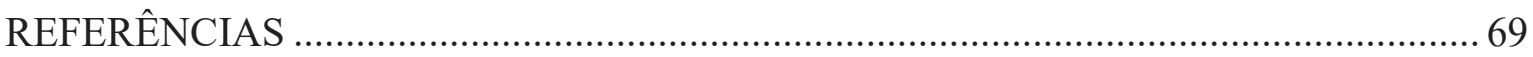

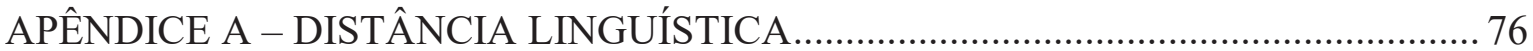




\section{INTRODUÇÃO}

Há uma grande transformação em progresso nos fluxos de comércio internacional, intensificada com a criação de um sistema de comércio multilateral e pela transição da produção fordista para flexível em muitas economias mundiais. Além do crescimento da escala de demanda entre os países membros em razão das reduções ou eliminações de barreiras em acordos bilaterais ou multilaterais, o surgimento de novos setores de produção, novas formas de fornecimentos de serviços financeiros e de comunicação via satélite, melhorias envolvendo os processos logísticos (reduções do custo de transporte), juntamente com o aumento da inovação, seja ela comercial, tecnológica e organizacional, reduziram as barreiras naturais do comércio internacional. $\mathrm{O}$ avanço tecnológico estimulou a evolução dos caminhos comerciais que, consequentemente, originaram as empresas multinacionais. Elas apresentam liderança dentro do desenvolvimento da globalização econômica, por meio da integração de redes mundiais de comércio, que só foram desenvolvidas graças a presença de informações confiáveis transmitidas entre as redes (BUTTON, 2010; CÉSAR, 2013; HARVEY, 1994; VEMURI; SIDDIQI, 2009).

Os efeitos da transformação no comércio internacional foi uma maior integração produtiva e comercial entre países, inclusão de certas economias em nichos de mercados especializados, ampliação da escala de produção, juntamente com economias de escala de empresas internacionais e fragmentação das cadeias de suplementos ou de insumos intermediários. A fragmentação global gerada no processo produtivo por meio do ritmo acelerado da inovação e transformação produtiva dentro da área de comunicação e transportes gerou o conceito de cadeias globais de valor (CGV), que reproduz uma divisão internacional das tarefas, consequentemente, levando a um novo sistema produtivo integrado, organizado em etapas sequenciais ou de redes (STEPHENSON, 2015). De modo igual, no início dos anos de 1980 surgiu o conceito de Supply Chain Management (SCM) ou cadeia logística, que denota a fragmentação dos processos logísticos, impulsionados pelas atividades terceirizadas (BUTTON, 2010).

A compressão do espaço-tempo (HARVEY, 1994) e da nova ordem internacional (SILVA, 2000; WTO, 2011) formada por blocos comerciais reduziram as barreiras naturais de comércio. Assim sendo, os horizontes temporais apresentaram estreitamento e a cobertura espacial envolvendo a tomada de decisões pública e privada foram ampliadas (HARVEY, 1994). As relações comerciais que envolvem as economias mundiais necessitavam não apenas da competitividade das produções internas, mas também de práticas de proteção aos interesses 
nacionais e de acordos bilaterais ou multilaterais que envolvem, por exemplo, mudanças tarifárias e não tarifárias. Dentro das relações comerciais e atividades produtivas, cabe destacar o fator das informações, junto com o capital e trabalho. As atividades do setor de informação abrangem todas os processos que envolvem produção, processamento e distribuição da informação e conhecimento, além de provir serviços para as atividades bancárias, governamentais, gestão e contabilidade de estabelecimentos. A intensidade de informação na atividade econômica foi crescendo a partir das décadas de 80 e 90. No início dos anos 80, o setor de informação de países em desenvolvimento da região da Ásia e Pacífíco como Singapura, Indonésia e Malásia representavam, respectivamente, 25\%, 19\% e 14\% do Produto Interno Bruto (PIB) (WELLENIUS; STERN, 1994).

Para os países da Organização para a Cooperação e Desenvolvimento (OCDE), o setor de informação era responsável por um terço a metade do PIB e do emprego. A alta influência do setor nas atividades econômicas, juntamente com a globalização dos fluxos de capital, comércio, manufatura e outras atividades, aumentou a demanda por serviços de comunicação e informação, focados em uma melhor qualidade, variedade e preços. O aumento da demanda se uniu aos avanços tecnológicos das telecomunicações (microeletrônica, software e óptica), que reduziram o custo de transmissão e processamento de informações. Esses avanços alteraram as estruturas de custos do setor e de outras indústrias, justamente por melhorar o atendimento das necessidades de comunicação com custo baixo. Como resultado, houve a redução da dependência a entidades estabelecidas dentro do setor de telecomunicações e aumentou a incorporação entre informações integradas e serviços/tecnologias em telecomunicações. A partir desse ponto, as telecomunicações se caracterizavam como investimento estratégico a fim de manter e desenvolver vantagem competitiva em todos os níveis: nacional, regional e empresarial. Dessa maneira, as telecomunicações se estabeleceram como núcleo e fornecimento de infraestrutura para a economia da informação (WELLENIUS; STERN, 1994).

O surgimento da Internet e da tecnologia móvel na década de 90, junto com a propagação da globalização, propulsionaram a disseminação das aplicações das TICs (Tecnologia da Informação e Comunicação) nos setores e nações (JORGENSON; VU, 2016). A porcentagem de indivíduos usando Internet em 1993 correspondia a 0,3\% da população mundial. Em 2017, essa porcentagem era de 49\%. O número de assinaturas de telefones celulares aumentou de 11 milhões em 1990 para mais de seis bilhões em 2019 (WORLD BANK, 2020).

A disseminação das TICs em todos os cantos do mundo teve efeito no desenvolvimento econômico, exclusivamente em áreas baseadas na comunicação, acesso à informação, aprendizagem, pesquisa e inovação (JORGENSON; VU, 2016). O fluxo de informação nos 
países em desenvolvimento cresceu no final dos anos 90, tanto que para países como Brasil e México, que passaram pela reforma do setor das telecomunicações na América Latina nessa época, o número de assinaturas em banda larga que eram 1.000 para o Brasil e 0 para o México em 1998, passaram para 100.000 e 15.000 assinaturas, respectivamente, nos anos 2000. Dado a taxa a cada 100 pessoas, essas assinaturas apresentaram impacto ínfimo dentro da população de ambos os países. No ano de 2018, o número de assinaturas no Brasil e no México são de 31.233.004 e 18.359.028, respectivamente, representando que a cada 100 pessoas, 14,9 e 14,5 possuem assinatura de banda larga em casa. Para comparar, pegando como exemplo países em situações superiores como os Estados Unidos e China, as assinaturas de banda larga a cada 100 pessoas de ambos os países são de 33,9 e 28,5 em 2018 (WDI, 2020).

Atendendo o comércio internacional entre países, cabe destacar que a superioridade de informações pode ser um fator que interrompe barreiras de entrada no mercado. Há impedimentos relacionados as barreiras informais que prejudicam o comércio, que podem ser frutos do governo com intuito de favorecer interesses nacionais sobre os estrangeiros, ou até subproduto de práticas e políticas enraizadas em instituições (DEARDORFF; STERN, 1997). A reforma do setor das telecomunicações na América Latina nas décadas de 80 e 90 servem como exemplo dentro do contexto abordado, uma vez que alguns governos estavam com problemas fiscais graves, como o Brasil. Esse problema causava ineficiência ao setor do país, pois não atendia a inovação e a progressão do setor das telecomunicações. Consequentemente, houve uma disseminação baixa de informação e comunicação em relação a outros países. As telecomunicações são meios facilitadores de entrada no mercado, de melhora no atendimento ao cliente, de redução de custo e de aumento da produtividade (WELLENIUS; STERN, 1994). Esse obstáculo pode advir da baixa troca de informações entre países aonde a penetração das TICs ainda é baixa. A Internet, por exemplo, é o canal de informação e comunicação com alta presença no ambiente globalizado, dado que a disseminação das TICs desde os anos 90 vem conectando diversos países dos melhores padrões de desenvolvimento aos países mais isolados e pobres. Essa barreira ao comércio internacional cria certa vantagem para antigos parceiros que, por algum tipo de proximidade cultural ou linguística, criam laços que podem ser revertidos em benefícios econômicos entre as nações. A propagação do mercado internacional nos canais de informação, ainda mais em um cenário em que 49\% dos indivíduos mundiais possuem acesso à Internet (em 2017), pode atuar como ferramenta para a diminuição da barreira natural gerada pela falta de fluxo informacional e comunicativo entre países (WORLD BANK, 2020). Ou seja, a melhora das TICs e aumento da velocidade de propagação da informação são fatores que podem beneficiar outros mercados, devido à ligação entre fabricantes, atacadistas e 
varejistas geradas pela integração, por exemplo, de mercado de commodities, serviços financeiros e transportes, e serve como auxílio para a diminuição da concentração comercial entre países (WELLENIUS; STERN, 1994).

Esta dissertação contribui para esse mote de pesquisa e tem como objetivo principal analisar o efeito da Internet no comércio internacional levando em conta um grupo de países em distintos estágios de desenvolvimento. Mais especificamente, este estudo aborda a penetração da Internet como instrumento de diminuição das barreiras comerciais, juntamente com a evolução tecnológica das telecomunicações. Espera-se que a penetração da Internet auxilie na diminuição dos custos comerciais, devido aos impedimentos que a falta do fluxo de informações pode gerar na interação entre países dentro do mercado internacional. A estratégia de análise consiste em avaliar o efeito da Internet e das TICs dentro de mudanças tecnológicas conhecidas no período entre 2000 e 2016, com ênfase nos efeitos ao fluxo comercial agregado e desagregado para os setores da economia. A abordagem levando em consideração a distância linguística na discussão dos resultados também merece ser destacada, avaliando o impacto da característica dentro de diferentes setores da economia.

A hipótese é que a penetração da Internet, juntamente com a evolução tecnológica das telecomunicações, influenciou positivamente no fluxo do comércio, diminuindo o efeito das barreiras comerciais entre países, sejam elas referentes a distância linguística, cultural ou informacional. A dissertação busca contribuir ao explanar detalhadamente os efeitos que as tecnologias de informação e comunicação incidem dentro do comércio internacional, resolvendo posições que independem de relações históricas e políticas entre países. Avaliar o efeito das outras variáveis determinantes dentro do recorte temporal e da desagregação em níveis setoriais ajuda a entender para qual caminho a evolução das telecomunicações está conduzindo os fluxos comerciais entre países. O refinamento dos resultados na conclusão do estudo pode atuar como referência dentro da discussão acerca de políticas comerciais, dado que o setor das telecomunicações tem sido central em instrumentos de políticas e gera efeitos positivos sobre o fluxo comercial. A colaboração para a literatura relativo à documentação das estratégias adotadas, juntamente com consistência das estimações também entra como contribuição, abordando questionamentos e sugestões acerca de estratégias que podem melhorar os resultados encontrados.

Para atingir o objetivo principal desta dissertação, serão estimadas equações gravitacionais para o comércio internacional, considerando o método Poisson-Pseudo Maximun Likelihood (PPML). O método trabalha com a correção da heterocedasticidade e fluxos comerciais nulos. A estimação apresentará efeitos fixos para controlar as resistências 
multilaterais ao comércio, e defasagens envolvendo a variável de penetração da Internet e os acordos regionais de comércio, para corrigir possíveis problemas de endogeneidade.

\subsection{Estrutura da dissertação}

Além deste capítulo introdutório, essa dissertação se organiza em mais seis capítulos. $\mathrm{O}$ capítulo 2 trabalha com a revisão da literatura envolvendo o comércio internacional e as TICs, explicitando primeiramente a abordagem histórica e teórica sobre o tema e finalizando com a revisão empírica relacionada a estudos aplicados que trabalham com a temática, com suas respectivas abordagens e modelos utilizados. O capítulo 3 discute a metodologia proposta, através da derivação teórica do modelo gravitacional aplicado ao comércio internacional. Há também a descrição da base de dados, abordando tratamento dos dados, fonte de obtenção e justificativas de utilização. O capítulo também expõe as estratégias empíricas como tratamento para endogeneidade, heterocedasticidade e fluxos comerciais nulos, juntamente com a estratégia de análise do modelo gravitacional dentro do período 2000-2016. O capítulo 4 compreende a interpretação dos resultados obtidos, além dos testes e abordagens adotadas. Por fim, o último capítulo expõe as considerações finais da dissertação. 


\section{COMÉRCIO INTERNACIONAL E INFORMAÇÃO}

\subsection{As tecnologias da informação e da comunicação (TIC) nas economias mundiais}

Dentro do escopo da quarta revolução industrial, as indústrias demandam muito os serviços de telecomunicações com objetivo de criar sistemas altamente interconectados, buscando descentralizar e automatizar a produção, para aumentar competitividade e produtividade. No período contemporâneo, as tecnologias digitais 5.0 ou 4.0 se adaptaram às necessidades das indústrias manufatureiras, constituindo assim um novo estágio industrial. Dado isso, novos padrões foram oferecidos, como fabricação inteligente, Internet, serviços na nuvem, big data e análise dos dados para tomada de decisões (FRANK; DALENOGARE; AYALA, 2019). O aumento da competitividade e produtividade fruto da evolução e automatização da produção, consequentemente, influencia positivamente no comércio interno e externo dos países. Todavia, a evolução comercial não apresenta vantagens iguais para todos os membros no globo, já que países mais pobres possuem menor prática de comércio do que países ricos. Geralmente, esses países possuem uma distância maior (e.g. geográfica, de idioma, cultural e de barreiras políticas) com parceiros comerciais quando comparados com os países ricos. Há também a possibilidade da ineficiência dos serviços de telecomunicações dentro dos países mais pobres. Os investimentos em TIC podem indicar uma via para a superação dessas barreiras, tornando os países em desenvolvimento mais propensos ao aumento do comércio bilateral com outros países, consequentemente, aumentando a riqueza ao longo do tempo (DEMIRKAN et al., 2009). Um exemplo de evolução das telecomunicações mundiais está nos movimentos de liberalização do setor de telecomunicações nos anos 80 e 90, que mudaram estruturas produtivas e atuações de vários países no comércio internacional.

Dentro do escopo relacionado a aumento da competitividade e produtividade, o desenvolvimento da teoria do ciclo do produto, elaborado por Vernon (1966), tinha como objetivo analisar os determinantes do surgimento de certos produtos em determinado país, e quais fatores auxiliam o deslocamento da produção, após padronização do produto, para outros países. Vernon pontua que havia certa desarmonia da teoria neoclássica ao acatar apenas os custos relativos dos fatores produtivos e as vantagens comparativas para determinação dos fluxos internacionais de comércio, deixando de fora outros elementos como: economias de escala, inovações e a presença de informações limitadas. O acesso ao insumo de conhecimento tecnológico pelas empresas que possuam condições de acesso é igual em qualquer país, dado que eles façam parte do mundo desenvolvido. O empresário necessita compreender 
oportunidades econômicas em outras localidades para que o conhecimento científico seja aplicado na geração de novos produtos, ou seja, possuir conhecimento prévio do mercado. Ele só estará apto a investir em uma nova necessidade de consumo se sua renda compensar o investimento inicial na inovação. O produto passa por três estágios de desenvolvimento: produto novo, produção em maturação e produto padronizado. No primeiro estágio, há uma experimentação de fornecedores e insumos, dado que qualquer tipo de inovação pode sujeitar ganho de concorrência em relação a outros produtos novos. No segundo estágio, com a maturação do produto, há ênfase na concorrência, já que o número de produtores aumenta, sendo necessário esforços com intuito de gerar diferenciação da produção. A estabilidade da produção gerada pela padronização do produto gera esforços para a projeções de custos e controle eficiente dos mesmos. $\mathrm{O}$ aumento da demanda em países competitivos na produção estabelecida pela empresa detentora do monopólio da inovação começa a gerar necessidades de investimentos em nova instalação produtiva fora do país de origem, caso o custo do produto marginal mais o custo de transporte for maior que o custo unitário de produção potencial no mercado importador. A projeção do custo sempre terá imprecisões, devido à incerteza em relação ao futuro. Nesse estágio, a intensidade de trabalho em conhecimento diminui, consequentemente, aumenta a intensidade de trabalho em produção. Os países menos desenvolvidos nesse estágio podem oferecer vantagens competitivas em relação a localização da produção, já que produtos altamente padronizados possuem alta acessibilidade, sendo atrativos para países que tem à disposição mão-de-obra relativamente mais baratas (PESSOA; MARTINS, 2007).

Nas últimas cinco décadas, a redução de controles sobre a conta capital e financeira dos países, as diminuições tarifárias estabelecidas em acordos bilaterais ou multilaterais, bem como o desenvolvendo e a difusão de novas tecnologias em diversas áreas setoriais, impulsionaram a integração comercial, produtiva e financeira das economias mundiais. Cada vez mais países desenvolvidos e em desenvolvimento passaram a compor um extensivo fluxo de capital internacional e uma complexa cadeia de suplementos e de bens. Consequentemente, as flutuações sobre a propriedade e renda do capital ganharam uma escala global e tornaram-se mais intensas com os avanços da comunicação via satélite e a liberalização financeira. Tanto os horizontes temporais e quanto à cobertura espacial da tomada de decisões público e privada estreitaram-se, permitindo que as famílias invistam em seu próprio país doméstico como também em países estrangeiros (ATHREYE; CANTWELL, 2007; LOS; TIMMER; DE VRIES, 2015; MALLIDIS; DEKKER; VLACHOS, 2012; STIGLITZ, 2010; WALMSLEY, 2002; WTO, 2011). 
Os países desenvolvidos pioneiros na liberalização dos setores de telecomunicações, como os Estados Unidos e o Reino Unido, promoveram nos anos 90 aberturas de mercados semelhantes em outros países a partir de negociações multilaterais e bilaterais que geraram novos acordos internacionais de comércio e regulamentação, como o Acordo de Livre Comércio Canadá - EUA de 1989 que liberalizou pela primeira vez o comércio de serviços de telecomunicações. Em 1985, os Estados Unidos incluíram serviços pela primeira vez no comércio multilateral no Acordo Geral de Tarifas e Comércio (GATT) (WELLENIUS; STERN, 1994). Outros acordos envolvendo a integração regional no comércio entre países são evidenciados na IX Conferência Ministerial da Organização Mundial do Comércio (OMC), marcada pelo surgimento do novo Acordo de Facilitação de Comércio (FTA), negociado por mais de 150 países. Entre os pontos discutidos e negociados, cabe enfatizar a criação de compromissos envolvendo à tramitação das operações de importação e exportação, a previsão de cooperação entre os membros da OMC em questões aduaneiras e a disponibilidade de auxílios aos países menos desenvolvidos com intuito de prover a adequação das novas regras. Portanto, com a defesa do novo FTA, os países acreditavam que as novas regras estabelecidas gerariam maior eficiência nas estâncias aduaneiras de todo o mundo e, como consequência, reduziria os custos afiliados ao comércio de mercadorias (DONG; MEYERS, 2014).

A participação dos países em acordos comerciais é justificada pelos eventuais benefícios econômicos, ou seja, aqueles que podem reduzir barreiras comerciais entre países participantes, que impedem que tais transações sejam alcançadas caso as mesmas existem. De modo geral, a redução das barreiras comerciais serve como incentivo para o aumento do comércio entre as regiões que integram os acordos, consequentemente, gerando a possibilidade de aumento dos investimentos internos e externos. Cabe ressaltar que estes ganhos, gerados pela integração entre países, são classificados como ganhos tradicionais. Além desses ganhos, cabe mencionar a presença dos ganhos não tradicionais, presentes na literatura de Fernandez (1997) e Whalley (1998) em que avaliam a existência de ganhos não tradicionais no processo de integração, seja elas no apoio de reformas internas, acesso seguro ao mercado ou até voltado pela segurança e maior poder de negociação.

As telecomunicações entram com papel duplo, tanto na forma de serviço comercializável como na forma de entrega de outros serviços. O novo ambiente produtivo estabelecido entre os anos 80 e 90, em que a produção era descentralizada e globalizada, e que havia a necessidade de enfrentar o ambiente competitivo devido ao alto número de fornecedores, era caracterizado pela necessidade de adaptação dos produtos devido as mudanças da demanda referente à quantidade, cor, tamanho e outras características distintivas. O recebimento de pedidos e o 
tempo de produção começaram a caminhar próximos, já que a diferenciação dos produtos para diversos mercados necessitava atender todos ao mesmo tempo (WELLENIUS; STERN, 1994).

O ambiente de marketing e produção gerado entre os anos 80 e 90 necessita de contínua interação e comunicação entre a produção, fornecimento, equipes de design e vendas, distribuidores e clientes localizados em todo o mundo. Grandes empresas multinacionais exigiram a liberdade de configurar, gerenciar e controlar as redes de telecomunicações, devido ao papel central da mesma dentro do sistema produtivo. Era necessário flexibilidade em relação as informações públicas e privadas, para gerar combinações que atendessem o esperado quando necessário, ou seja, capacidade e instalação de redes de telecomunicações sem ter que pagar pelo excesso nem excedente de capacidade e instalações quando não são requisitadas. A flexibilidade que as multinacionais possuíam nos Estados Unidos, ocasionadas pelo processo de liberalização das telecomunicações geraram pressões em governos, inclusive de países em desenvolvimento, a concordar com comércios mais liberais com regimes regulatórios (WELLENIUS; STERN, 1994).

Com a globalização, a produção das empresas transnacionais e o comércio internacional cresciam mais que o dobro da taxa de produção mundial nos anos 90, junto com o aumento do tráfego telefônico internacional cerca de cinco vezes a taxa de crescimento mundial ${ }^{1}$. A competitividade econômica começou a ter novos determinantes críticos, como a alta qualidade dos sistemas e serviços de telecomunicações. O rápido desenvolvimento das tecnologias de informação intensificou a fragmentação produtiva em todo o mundo, juntamente com a moldagem pela crescente globalização produtiva e expansão do comércio internacional. A redução dos custos, aumento da flexibilidade do suprimento e as vantagens obtidas no mercado foram obtidas pelas inovações pertencentes as tecnologias da informação e comunicação (WELLENIUS; STERN, 1994). Em geral, as empresas estabelecidas nos setores de alta tecnologia e de negócios tornaram-se cada vez mais dependentes dos serviços de telecomunicações com intuito de aumentar a competitividade dentro da internacionalização da produção e consumo (COLECCHIA; SCHREYER, 2002; INKLAAR; TIMMER, 2007).

A capacidade das tecnologias de informação e comunicação começou a ser visualizada como instrumento estratégico que indicava ganho de participação e entrada em novos mercados. O aprimoramento da comunicação e recursos computacionais fornecem um caminho para o

\footnotetext{
1 Tanto o montante e quanto à natureza da distribuição física dos bens acompanharam as transformações do comércio internacional (HESSE; RODRIGUE, 2004), que cresceu de US\$ 57,5 bilhões para US\$ 3.600 bilhões entre 1948 e 1992 (TAVASSZY et al., 2011).
} 
maior crescimento das empresas, tornando a produção mais complexa e gerando acordos conjuntos tanto de manutenção quanto de produção. A difusão e inovação das telecomunicações tornaram as economias nacionais interdependentes, em que as telecomunicações atuam como força motriz, gerando conceitos globais de mercado, concorrência e estratégias de marketing. As decisões locacionais das fábricas, os projetos e as pesquisas são realizados tendo como foco vantagens em relação ao alcance global (WELLENIUS; STERN, 1994).

Após o estabelecimento das redes de informação como um papel chave quanto às crescentes exigências da economia global, a partir dos anos 80, as mesmas se desenvolvem pautadas em instrumentos políticos, que são atrativos para o desenvolvimento de economias regionais ou nacionais. Capacidade de serviços em telecomunicações, junto com regras de utilização, são fatores cruciais na decisão das empresas em estabelecer suas sedes regionais, bem como localização dos seus serviços e linhas de produção. O progresso tecnológico trouxe a mudança na velocidade de se comunicar e fazer negócios, gerando oportunidades e ameaças para governos e empresas. A efetiva aplicação da tecnologia acarretará em aumento no crescimento econômico e ganho de mercado. Entretanto, uma inapropriada aplicação da mesma pode reduzir tendências competitivas e, portanto, perder participação nos mercados internacionais. As reformas em telecomunicações nos países em desenvolvimento dos anos 80 e 90 tinham como foco o controle fiscal e gestão das dívidas, não focando prioritariamente nas questões envolvendo o desenvolvimento econômico estratégico (WELLENIUS; STERN, 1994). Entretanto, economias menos desenvolvidas com setor de telecomunicações privatizado e operando em plena competição tendem a gerar maiores efeitos sobre o crescimento da economia (LAM; SHIU, 2010). Há também a crença relacionada ao desenvolvimento de um setor privado nascente nos países em desenvolvimento, além da expectativa da melhora do investimento agregado do setor privado (ROS; BANERJEE, 2000).

O movimento de reestruturação do setor de telecomunicações foi também rápido e expressivo na América Latina, passando por Chile, Argentina, México e Venezuela, e em 1993, diversas etapas distribuídas entre os países: Bolívia, Brasil, Colômbia, Equador, El Salvador, Honduras, Panamá, Peru e Uruguai. Reformas estruturais ocorreram nessa região desde o final dos anos 80, através da substituição do modelo tradicional do monopólio estatal de telecomunicações dos anos 60, buscando soluções advindas do setor privado, indicando o aumento da concorrência, mudando o papel do governo de propriedade e operação para política e regulamentação (WELLENIUS; STERN, 1994). Entre 1986 a 1995, o setor privado de 
provisão de serviços básicos de telecomunicações em 17 países ${ }^{2}$ era pelo menos 50\% pertencente ao setor privado. Dez desses países estão localizados na América Latina. A maior privatização latino-americana ocorreu no Brasil em julho de 1998, quando a TELEBRÁS foi vendida por aproximadamente US\$ 19 bilhões, com intuito de seguir a tendência de eliminar a participação acionária do estado nas telecomunicações (ROS; BANERJEE, 2000).

No início dos anos 90, o Brasil possuía o segundo maior sistema de telecomunicações do mundo em desenvolvimento, sendo superado pela $\mathrm{China}^{3}$, com cerca de 10 milhões de linhas telefônicas ativas. O fornecimento de serviços e redes de telecomunicações era feito principalmente pela empresa Telecomunicações Brasileiras S.A. (TELEBRÁS), junto com a Empresa Brasileira de Telecomunicações (EMBRATEL), interestadual e internacional empresa de longa distância. Desde a sua fundação nos anos 60, a TELEBRÁS conseguiu construir um ambiente moderno com rápido crescimento da infraestrutura de telecomunicações no Brasil. Todavia, a deterioração geral do Brasil gerada pelas condições econômicas da década de 80 (destaca-se as restrições do investimento no setor público e ao crédito internacional), a empresa não conseguiu aderir o ritmo de inovação e crescimento. Os controles de preços governamentais não permitiam a TELEBRÁS recuperar custos e gerar excedentes para reinvestir, gerando alto custo de equipamentos, impossibilitando a melhora das redes e travando a modernização da estatal responsável pelo desenvolvimento das telecomunicações no país. Tais problemas geraram a deterioração da qualidade do serviço e afetaram o desenvolvimento de setores de negócios modernos e dinâmicos do Brasil (WELLENIUS; STERN, 1994).

A disponibilidade e uso de ferramentas associadas às Tecnologias de Informação e Comunicação melhoraram situações relacionadas a insuficiência de informações comerciais, além de diminuir as barreiras e distâncias comerciais (WANG; CHOI, 2019). A falta de comunicação efetiva dificulta a coordenação e efetivação de negócios entre parceiros comerciais. A inovação tecnológica gera expansão dos negócios, além da transformação do mercado. Os avanços relacionados à tecnologia da comunicação facilitam o comércio internacional, devido à possibilidade de várias transações serem realizadas eletronicamente. $\mathrm{O}$

\footnotetext{
2 Hong Kong, Filipinas, Espanha, Reino Unido, Barbados, Belize, Canadá, Estados Unidos, Jamaica, México, Nova Zelândia, Argentina, Bolívia, Chile, Guiana, Peru e Venezuela.

3 Segundo Lam e Shiu (2008), a entrada da China na OMC simbolizou um passo expressivo para o futuro desenvolvimento e reforma do setor. Como salientam os autores, a China tornou-se o principal atuante e fornecedor dentro do segmento de TIC, que está em rápido crescimento no mundo. Além de que, em 2019, a China permaneceu como um dos principais mercados de telecomunicações do mundo, atendendo a cerca de 191 milhões de clientes de telefonia fixa, 449 milhões de banda larga fixa e 1,725 bilhão de linhas móveis (WORLD BANK, 2020).
} 
meio eletrônico melhora o processamento de informação, além de reduzir o processamento de pedidos e pagamentos (ZHANG et al., 2020).

Antes da comercialização da Internet, o alto risco existente nas transações internacionais devido à falta de informações só conseguia ser evitado se fossem assumidos e implementados investimentos em tecnologia da informação ou construindo canais privados com objetivo de adquirir informações. Exemplos desses investimentos representam o aluguel de linhas telefônicas, o intercâmbio eletrônico de dados e a transferências eletrônicas de fundos. Primordialmente, o acesso a essas infraestruturas eram restritas a empresas maiores e multinacionais. A Internet e as infraestruturas das TIC desenvolvidas posteriormente possibilitaram a entrada de pequenas empresas e outros fornecedores, junto com melhor acesso ao mercado internacional (VEMURI; SIDDIQI, 2009).

A disponibilidade das TIC gera economias de recursos entre os participantes das redes criadas em diferentes níveis da cadeia de valor ${ }^{4}$ ao internalizar as externalidades da rede, representado pelo benefício marginal obtido mediante a interação com outros participantes da cadeia de valor, por exemplo, advindo da troca de informações de mercado. As empresas pequenas e médias apresentam uma desvantagem ao participarem de redes, pois não estão equipadas para acompanhar o desenvolvimento evidenciado pelas outras empresas e nem para conseguir participar das redes. Não obstante, a criação das redes proporcionadas pelas TIC evolui a economia como um todo, podendo causar a queda dos custos para as empresas pequenas e médias em relação aos serviços de apoio do comércio, como seguros, gerenciamento de estoque, rede de distribuição, propaganda e gerenciamento do relacionamento com cliente (CHUNG; FLEMING; FLEMING, 2013). As TIC são difundidas de forma desigual entre países, gerando assim uma “divisão digital”. Nesse sentido, há o aumento da diferença de crescimento entre os mesmos, pois países com maior acesso as TIC conseguem tirar proveito maior em termos econômicos do que os que não possuem a mesma oportunidade. Por exemplo, os Estados Unidos, Finlândia e Irlanda, que conseguiram absorver ao máximo as oportunidades proporcionadas pelas TIC na década de 1990, apresentaram resultados elevados na geração de emprego e no crescimento econômico quando comparados com outros países europeus e com o Japão (SEO; LEE; OH, 2009).

\footnotetext{
${ }^{4}$ Originando, respectivamente, conceitos como cadeias globais de valor (CGV), um sistema produtivo organizado em etapas sequenciais (TIMMER; DE VRIES, 2015). Esse conceito denota um conjunto de atividades necessárias de uma organização desde as relações com os fornecedores, ciclos produtivos e de venda até a entrega do produto ao consumidor final. As etapas podem ser desempenhadas por uma ou mais organizações. Se o conjunto de organizações encadeadas se localizarem em mais de um país, temos uma cadeia de valor global (FGV, 2020).
} 
Nos países em desenvolvimento, o alto custo das informações ocasiona a falta das mesmas, restringindo as tomadas de decisões, graças ao desconhecimento dos agentes. $\mathrm{O}$ mercado acaba se tornando ineficiente, já que abre a possibilidade da existência da assimetria da informação, gerando vantagens para agentes com capacidade econômica de obter informações. A infraestrutura de telecomunicações tem a capacidade de reduzir os custos de transações, aumentando a produção agregada. Também apresentam aspectos positivos na redução da distância comercial e linguística entre países e regiões, pois facilitam o fluxo de informações. De modo geral, as telecomunicações reduzem os custos fixos de aquisição de informações e os custos variáveis da participação de mercados (NORTON, 1992). O impedimento comercial gerado pela distância geográfica, estabelecido por aplicações da equação de gravidade, caracteriza principalmente pela influência dos custos comerciais no comércio internacional (FINK; MATTOO; NEAGU, 2005). Cabe mencionar a presença dos custos de coordenação e de transações conectados a partir da localização dos ofertantes e demandantes. Além do custo de transporte, há custos comerciais que são gerados pelas distâncias e fronteiras como barreiras tarifárias e não-tarifárias, padrões de produção, impedimentos de comunicação e diferenças culturais (COMBES; MAYER; THISSE, 2008).

A presença de barreiras informacionais indica impedimento para a entrada no comércio internacional, pois países que compartilham idiomas, histórico e proximidade cultural tendem a realizar comércio entre si, pois essas variáveis apresentam papel significativo na redução das barreiras informacionais no comércio (CYRUS, 2012). O cenário comercial se reformulou devido às inovações baseadas nas Tecnologias de Informação e Comunicação, que ampliou os mercados das empresas, aumentando o número de clientes, a escala produtiva e os lucros. Essa revolução também causou o confronto entre as empresas concorrentes a nível mundial, incentivando ao acompanhamento das tendências de mercado. A infraestrutura tecnológica de um país cria ambiente para a adoção e evolução das TIC. As tecnologias de Internet determinam base de avanços contínuos de bens e serviços, novos mercados e modelos de negócios para a economia, gerando assim a base a para o desenvolvimento do comércio eletrônico (CLARKE; WALLSTEN, 2006; XING, 2018).

Um dos canais de impacto advindo das TIC no crescimento econômico é o comércio internacional, pois o uso delas leva ao aumento dos fluxos de comércio diretamente, devido ao aumento dos bens de TIC comercializados no mercado mundial, e indiretamente, pela utilização das TIC nas empresas que proporcionam redução de custos comerciais ou produtivos, fora a expansão das relações comerciais entre os países. A Internet está cada vez mais se tornando importante para contatos internacionais entre empresas, quando comparadas com comunicações 
por telefones fixos e móveis (YUSHKOVA, 2014). É necessário considerar que as diferenças entre países irão gerar difusões diferentes das TIC, devido ao nível de digitalização assimétrica entre e dentro dos países. Adoções diferentes das TIC causam disparidades que afetam ambos os países, exportadores e importadores. Com isso, há a necessidade de acatar as diferenças para fazer a análise precisa do efeito das TIC no comércio (RODRÍGUEZ-CRESPO; MARTÍNEZZARZOSO, 2019). O canal de comércio bilateral entre países possibilita que empresas de países em desenvolvimento e menos desenvolvidos possam aprender a reproduzir produtos ou adotar tecnologia de alto nível de parceiros comerciais desenvolvidos, para venda no mercado interno ou no mercado mundial (XING, 2018).

Em países com níveis semelhantes de complexidade dos produtos, a Internet induz a implementação de políticas direcionadas à redução do custo relacionado ao processo de conhecimento tácito, reduzindo assim as disparidades de renda entre os países mais desenvolvidos em relação aos menos. O conhecimento, separando as diferenças de rendas entre países, serve como base para que os menos desenvolvidos possam diminuir a diferença em relação aos desenvolvidos. O ganho de conhecimento induz os países especializados em produtos de menor complexidade a se inserirem em redes globais de produção, consequentemente, aumentando a competitividade com objetivo de enfrentar a globalização (RODRÍGUEZ-CRESPO; MARTÍNEZ-ZARZOSO, 2019). A disponibilidade de rede e a quantidade de infraestrutura das TIC no comércio ocasionam o crescimento das exportações, uma vez que incentivam as empresas produtoras e exportadoras a aumentar o comércio devido à multiplicação das cadeias globais de valor do comércio eletrônico (XING, 2018).

A utilização da internet gera e distribui informações junto com ideias descentralizadas nos mercados que recorrem cada vez mais as informações como insumos. O maior uso dessa tecnologia pode acelerar a distribuição das novas ideias e informações, acarretando no aumento da concorrência e desenvolvimento de novos produtos, modelos de negócios, consequentemente, facilitando o crescimento macroeconômico (SALAHUDDIN; GOW, 2016). Friedman (1999) destaca o papel da Internet na redução dos custos de comunicação como uma das principais razões da globalização. O autor menciona sobre a capacidade das novas tecnologias de informação de construir o mundo mais sólido, dado que essas tecnologias permitem que países em desenvolvimento não apenas troquem suas matérias-primas em produtos acabados, possibilitando também que eles se tornem grandes produtores. As tecnologias também proporcionam para as empresas a localização de partes diferentes de sua produção, pesquisa e marketing em outros países, unidos por meio de computadores e teleconferência em apenas um local. 
As Tecnologias de Informação e Comunicação fornecem aos comerciantes e empresas novas ferramentas para melhorar a eficiência, troca de informações e a formação de redes, especialmente se há dispersão espacial entre eles. Em relação aos telefones celulares, eles possibilitaram a comunicação com maior frequência e eficiência, elevando a velocidade de verificação de informações, reduzindo assim as assimetrias de informação (OVERÅ, 2006). De modo geral, a importância das TIC varia entre o sistema de produção, sistema de marketing e o status tecnológico do país, além da variação apresentada em relação ao atributo do produto que está envolvido no comércio (CHUNG; FLEMING; FLEMING, 2013).

A expansão e estabelecimento de negócios internacionais envolvem o uso, armazenamento e processamento de informações relevantes, sejam elas sobre fornecedores, mercados, preços, tendências tecnológicas e mercados de exportação ou importação. É necessária a presença de informações precisas e adequadas para o desenvolvimento de estratégias ótimas de penetração de mercado. As telecomunicações internacionais auxiliam na aquisição de informações de empresas inseridas em setores de bens comercializáveis, com isso, a intensidade de telecomunicações internacionais serve como indicador para o intercâmbio de informações nos mercados de bens. O processo de abertura das telecomunicações reduziu consideravelmente os preços na telefonia internacional, causando a ampliação no volume de telecomunicações. Consequentemente, há a facilidade de expansão para os mercados internacionais, em que sistemas de telefonia modernos e eficientes apresentam impacto positivo no comércio, tanto no interempresarial de multinacionais quanto no tradicional associado a ganhos de especialização (JUNGMITTAG; WELFENS, 2009).

Em relação à internacionalização da economia, a presença de custos de informações baratos e rápidos melhoram as transações de mercado e ampliam o raio do comércio internacional. O crescimento do comércio mundial é associado ao progresso tecnológico das telecomunicações e na queda dos custos de comunicação. Para países em desenvolvimento, a abertura da modernização das telecomunicações e do reequilíbrio das tarifas, em que preços são baseados em custos, influencia a arbitragem nacional quanto para facilitar o acesso às informações do mercado internacional, além de ser a base para a construção e instauração de redes internacionais de produção dentro de empresas multinacionais (FINK; MATTOO; NEAGU, 2005; JUNGMITTAG; WELFENS, 2009).

Modelar o papel dos custos de comunicação na economia é uma tarefa complexa, porque inclui os custos fixos ou variáveis do comércio, dependendo do papel que ela assume dentro da transação. Se ela for voltada para facilitar a busca de parceiros comerciais, os custos estão inseridos dentro de contextos irrecuperáveis. Todavia, ela pode estar envolvida na interação 
entre fornecedor e produtor, por exemplo, na especificação do produto e no tempo de processamento. Também pode estar relacionada com a necessidade de personalizar o produto com características específicas. Devido à essas interações diversas, que dependem da natureza do produto, os custos podem ser variáveis (FINK; MATTOO; NEAGU, 2005).

Há a possibilidade de que empresas com produtividade relativamente baixa se insiram nos mercados internacionais de países com infraestrutura adequada e aprimorada que facilitam o comércio. Um exemplo está relacionado à qualidade da infraestrutura de Internet que proporcionam uma facilitação que pode afetar os custos fixos da empresa em relação ao comércio. A interação entre fatores específicos da empresa, como por exemplo, a produtividade, com a utilização da Internet, determinada pela infraestrutura disponível de Internet no país sede da empresa, afeta os custos fixos de negociação de diversas maneiras (YADAV, 2014). O acesso à Internet também pode reduzir o custo de encontrar e se comunicar com clientes potenciais de outros mercados, aumentando a exportação de países em que a penetração da Internet é maior. Entretanto, se a Internet apenas substituir chamadas telefônicas e fax, é pouco provável que a mesma gere alto impacto nos custos da empresa exportadora, pois as despesas telefônicas e postais são bem baixas. A economia total do acesso à Internet será muito baixa se atuar apenas na substituição dos métodos de comunicação existentes (CLARKE; WALLSTEN, 2006).

O efeito da Internet nos países com diferentes estágios de desenvolvimento é distinto, de modo que pode ocorrer relações positivas entre as exportações dos países em desenvolvimento para países desenvolvidos, entretanto, a mesma relação não é evidenciada quando assumimos exportações de países desenvolvidos para países em desenvolvimento. Em países desenvolvidos, a penetração da Internet está correlacionada com os custos fixos de entrada relativamente altos nos países em desenvolvimento quando comparados com outros países desenvolvidos (CLARKE; WALLSTEN, 2006).

Com intuito de identificar os efeitos da Internet no comércio internacional, Freund e Weinhold (2004) desenvolvem um modelo de mercados segmentados e concorrência imperfeita, para demonstrar os possíveis efeitos da redução dos custos fixos de entrada das empresas, que podem ser ocasionados pela maior penetração da Internet. O modelo considerando segmentação de mercado e concorrência imperfeita, são características importantes para mercados em que há presença de custos fixos. As exportações são definidas pautadas em lucros e custos fixos, pois empresas não irão escolher comercializar com outros mercados onde os lucros são baixos e os custos fixos são altos, demonstrando um nível de concorrência diferente entre países. A concorrência perfeita e custos fixos não são consistentes 
nesse caso, por causa da falta de competição lucrativa no mesmo mercado de exportação, já que o custo médio excederia o custo marginal.

A disponibilidade efetiva da Internet reduz o custo fixo das empresas inseridas em um mercado. A intuição básica leva ao seguinte raciocínio: a Internet induz e auxilia as empresas a adquirir informações sobre países estrangeiros com mercados pertencentes ao ambiente online, servindo como ferramenta para as redes compartilharem informações sobre mercados específicos. Há uma efetividade em relação a redução dos custos de se realizar negócios em um país estrangeiro. Assume-se que há um indicador de conexão à Internet entre países, que representa certo ponto no qual o custo fixo é reduzido devido ao aprimoramento das informações recebidas. Favorável a essa redução, há um aumento nas exportações, pois as empresas entram no mercado externo. Entretanto, caso haja a entrada maior de empresas no mercado externo, a quantidade de exportação de cada empresa diminuirá, ocasionando menores lucros, causando assim um efeito menor de entrada nas exportações (FREUND; WEINHOLD, 2004).

O aumento da concorrência pode gerar o declínio nas exportações individuais de cada empresa, que terá maior efeito para as mais distantes. Isso se dá pelo fato das exportações se caracterizarem como substitutos estratégicos, ou seja, quando se elevam o número de empresas, as exportações totais crescem, diminuindo a quantidade de exportações de cada empresa. Há uma relação entre a exportação e proximidade, qual seja: empresas mais distantes geograficamente reduzem suas exportações em maior extensão quando comparadas com empresas mais próximas. Nesse sentido, o aumento da penetração da Internet no país importador apresenta associação com o aumento da entrada, gerando um efeito positivo da Internet na distância comercial, que pode induzir o crescimento do comércio (FREUND; WEINHOLD, 2004).

O crescimento da Internet ou redução nos custos fixos deve gerar a alta das exportações, o acréscimo no mercado de importação deve elevar as exportações, o aumento do número de exportadores ocasiona a redução do crescimento das exportações e o crescimento na distância média dos exportadores pode melhorar o crescimento das exportações. Entretanto, se a alta do mercado de importação for o principal causador pelo crescimento das exportações, provavelmente o efeito será maior em países mais distantes, pois o efeito marginal do tamanho do mercado em relação à quantidade exportada é constante e os países mais distantes exportam menos. O comércio mundial apresentará crescimento em resposta à Internet, desde que não haja um grande alongamento da distância média dos exportadores com os mercados. O ganho no número de exportadores compensa muito mais a queda na produção no nível da empresa, 
provavelmente causando redução no preço do bem imperfeitamente competitivo (FREUND; WEINHOLD, 2004).

Outro fator que pode ser benéfico para o crescimento das exportações realizadas por um país está relacionado com a diminuição do tempo de envio dos produtos, que é gerado por três componentes: documentação, tempo de trânsito e uso dos portos junto com desembaraço aduaneiro. Como estimado por Freund e Rocha (2011), o incremento de um dia do tempo de trânsito dos produtos reduz em média os valores das exportações em 7\% para países da África Subsaariana. As tarifas de exportação dos países da África Subsaariana apresentam níveis muito baixos, além de terem acesso preferencial a mercados como do Estados Unidos e União Europeia. Observou-se que há a presença de outros tipos de barreiras interferindo no desempenho do mercado internacional dos países africanos analisados. Hummels e Schaur (2013) enfatizam a parcela de produtos transportados pelo mundo através de aviões, mesmo sendo um meio de transporte mais caro que o transporte marítimo, porém, reduzindo o tempo de entrega do comércio. Os autores ainda destacam que cargas transportadas pelo oceano demoram em média 20 dias saindo de portos da Europa para os portos dos EUA e 30 dias para chegar no Japão. Cargas transportadas por meio de aviões requerem apenas um dia ou menos, dependendo do destino. O pós-guerra foi marcado pelo crescimento do comércio mundial devido à queda de tarifas e melhoria da tecnologia, relacionadas com informação e transporte. O comércio pode ser facilitado através da identificação de barreiras regulamentares e nãotarifárias, como por exemplo, por meio da simplificação de procedimentos aduaneiros e da melhoria na infraestrutura portuária, economizando assim dias de transportes de produtos. As TIC têm efeitos positivos no custo relacionado a distância, pois afetam o frete e o custo da comunicação ao mesmo tempo. Em relação ao frete, há a diminuição do custo de envio dos produtos, devido à diminuição do custo de coordenação .

\subsection{Efeitos da TIC no comércio internacional - revisão de enfoques}

Em termos de aplicação, a literatura aplicada utiliza principalmente uma abordagem econométrica para modelos gravitacionais estendidos ao comércio bilateral a fim de avaliar os impactos das tecnologias de informação e comunicação (TIC) em diferentes escalas setoriais e/ou regionais. Essas abordagens econométricas levam em conta tecnologias específicas ou um conjunto delas, como internet e telefones móveis, para referenciar e mensurar as infraestruturas de TIC em um país ou região. A seguir, os estudos aplicados são revisados por ordem 
cronológica, cujas análises se concentram ao comércio internacional entre países, especialmente para avaliar os efeitos sobre exportação e importação de bens, custos comerciais, abertura comercial, globalização, investimento estrangeiro direto (IED), migração e barreiras relacionadas ao fuso horário.

Essa revisão empírica também indica aperfeiçoamentos dos modelos e abre novas lacunas de análises que versam sobre a relação entre comércio internacional, informação e barreiras não tarifárias. Por exemplo, Freund e Weinhold (2004) avaliaram o estímulo da internet no comércio internacional em 56 países a partir de regressões de séries temporais e cross-sections, no período de 1995 a 1999. Os resultados conclusivos apontam que, um aumento de 10 pontos percentuais no crescimento de hosts em um país aumenta cerca de 0,2 pontos percentuais no crescimento das exportações. Há também a presença de evidências indicando crescimento enviesado por proximidade, ou seja, menor para países mais distantes, porém, sem evidências de que a Internet afeta esse viés. A redução nos custos fixos da Internet provavelmente irá gerar o crescimento das exportações, e a relação da Internet com a distância e o comércio internacional é indireta, ou seja, o aumento da concorrência devido ao desenvolvimento influenciado pela melhora nas telecomunicações, bem como eleva o efeito geral da relação entre distância e comércio.

Por seu turno, Fink, Mattoo e Neagu (2005) testaram a relação dos custos de comunicação como um dos determinantes nos custos comerciais, incorporando medidas alternativas de custos em um modelo gravitacional de comércio bilateral aplicado sobre os dados do Banco Mundial para o ano de 1999. As conclusões gerais dos autores salientaram que as variações internacionais nos custos de comunicação impactam significativamente os padrões comerciais e que os custos de comunicações são mais importantes no comércio de produtos diferenciados do que no comércio de produtos homogêneos.

Já Clarke e Wallsten (2006) questionaram se o aumento das exportações dos países em desenvolvimento para países desenvolvidos ocorre devido ao aumento da penetração da Internet ou se a abertura comercial incentiva o uso da Internet. Para testar essa hipótese subjacente, os autores consideraram o uso da Internet como endógeno, utilizando como instrumento a regulamentação dos serviços de dados dos países. A base de dados contém 98 países desenvolvidos e em desenvolvimento, correspondentes ao ano de 2001. Os principais resultados evidenciaram que o acesso à Internet melhora o desempenho das exportações dos países em desenvolvimento, não apresentando o mesmo resultado para países desenvolvidos. A análise sugere que o bloqueio da concorrência nas telecomunicações de um país, ponto que influencia 
o desenvolvimento da Internet, causa a redução da penetração da Internet e a queda nas exportações para os países mais ricos.

Por outro lado, Clarke (2008) analisou a relação da Internet como uma das forças que impulsionam a globalização, analisando se há correlação entre o acesso à Internet e o desempenho das exportações para empresas de países de baixa e média renda pertencentes à Europa Oriental e Ásia Central. Os dados advêm de cross-sections agrupadas, referentes aos anos de 1999, 2002 e 2005. Os resultados conclusivos mostram que, empresas conectadas à Internet têm maior probabilidade de exportar do que empresas similares que não estão conectadas. A conectividade tende a aumentar o desempenho das exportações, e os resultados são robustos quando incluímos outras variáveis a fim de controlar outros fatores que podem interferir o acesso à Internet e o desempenho das exportações. O controle serve também para tentar exaurir o viés de auto seleção.

Similarmente aos estudos supracitados, Demirkan et al. (2009) avaliaram se as TIC reduzem os custos associados ao comércio internacional entre países, com base em fluxos comerciais bilaterais e dados sobre distância geográfica de 175 países diferentes para o ano de 2005. Os autores utilizam um tradicional modelo gravitacional, com dados estatísticos coletados do banco de comércio e commodities da ONU, com intuito de determinar se as distâncias culturais e físicas são importantes na atuação das TIC nos fluxos comerciais. A metodologia envolve 14.551 combinações de países com intuito de identificar o efeito da distância entre eles no comércio. As estimativas desse estudo aplicado apontaram que fluxos comerciais são maiores entre países com maior uso de Internet, indicando que infraestrutura digital comum entre países aumentará o comércio. O uso das TIC impacta mais positivamente os fluxos de economias maiores, quando comparados com o impacto das economias menores, além de melhorar o comércio de países mais distantes quando comparado com os mais próximos.

Nessa mesma linha de análise, Choi (2010) averiguou o efeito da Internet no comércio, exportação e importação de serviços, com posse de dados em painel de 151 países de 1990 a 2006. Para tanto, o autor utilizou regressões de mínimos quadrados ordinários combinados, modelo de efeitos fixos e método dos momentos generalizados (GMM) em painel a fim estimar o modelo gravitacional de comércio. Os resultados designam que um aumento de $10 \%$ no número de usuários da Internet por cem pessoas aumentou a exportação de serviços para $0,43 \%$ e a importação de serviços em $0,38 \%$, ao acatar o efeito da possível endogeneidade entre o comércio de serviços e o uso da Internet, utilizando para a estimação o painel GMM. O efeito é significativo, porém pequeno, pois se trata do comércio agregado de serviços. 
Por sua vez, Lee (2012) estudou o papel das redes de Investimento Estrangeiro Direto, migração e Internet no aumento do comércio internacional, especialmente devido ao papel das redes sociais e de negócios como meio para superar as barreiras informais. Os autores trabalham com o modelo gravitacional, levando em consideração a base de dados de 21 países bilaterais da OCDE correspondente ao ano de 2008. Os resultados foram robustos para diferentes tipos de redes e especificações do modelo gravitacional, e indicam que a Internet é o canal mais importante ao assumir o efeito de rede nos setores de manufatura e serviços, enquanto a migração é responsável apenas pelo setor da manufatura. Os resultados realçam a importância do efeito de rede e a diferença entre as redes no comércio internacional quando separadas por setores, além de enfatizar o papel da Internet quando comparada com as duas redes analisadas.

Já Chung, Fleming e Fleming (2013) avaliaram se as Tecnologias da Informação e Comunicação afetam positivamente o comércio bilateral de frutas e legumes entre os países membros da Cooperação Econômica Ásia-Pacífico (APEC), utilizando como ferramenta de análise o modelo gravitacional para o comércio internacional. A análise busca observar se o uso da Internet, telefones celulares e linhas telefônicas fixas são responsáveis pela determinação do valor do comércio bilateral. Os autores empregam a estimação por máxima verossimilhança de pseudo-poisson (PPML), durante o período de 1997 a 2006. Os resultados conclusivos apontam que, a importância das tecnologias se difere entre as importações e exportações na cadeia internacional de valor de frutas e legumes. Alterações nos níveis de TIC referentes ao setor de importação não afetam o comércio internacional dos países da APEC, mas alterações no setor de exportação têm efeitos positivos significativos no comércio de frutas e legumes. O efeito mais acentuado foi observado nas linhas telefônicas fixas, e em relação às TIC digitais, apenas a Internet teve impacto significativo no comércio de frutas e legumes.

Por seu turno, Liu e Nath (2013) analisaram o efeito das Tecnologias de Informação e Comunicação no comércio internacional dos mercados emergentes, a partir do painel de dados de 40 países emergentes entre 1995 a 2010. O modelo utilizado considera efeitos fixos e utiliza como principal variável explicativa de interesse as Tecnologias de Informação e Comunicação para os níveis de exportação e importação. Os resultados sugerem que assinaturas e hosts de Internet têm resultados significativos e positivos no comércio internacional dos países emergentes, indicando que é necessário o uso das tecnologias no país, não apenas a disponibilidade ou infraestrutura.

Por outro lado, Dettmer (2014) investigou se o fuso horário atua como força motriz ou como barreira comercial do comércio internacional de serviços empresariais e gerais, e se o mesmo depende do acesso à tecnologia da informação e comunicação. A autora utilizou o 
modelo de gravitacional com medidas de fuso horário e variáveis que reproduzem as infraestruturas de TIC. O estudo concluiu que o fuso horário representa uma barreira à negociação com parceiros localizados no mesmo fuso horário, já que fornecedores de serviços preferem lucrar com a diferença de fuso horário.

Bankole et al. (2015) avaliaram o desdobramento da infraestrutura das TIC no comércio da África, no contexto de fatores complementares, como qualidade institucional e desempenho educacional, que contribuem para os fluxos comerciais bem-sucedidos para o período de 1998 a 2007. Os autores, através de uma análise com modelagem de equações estruturais com mínimos quadrados parciais, confirmam que a infraestrutura tem impacto direto no comércio, além de impacto indireto em relação à influência na qualidade institucional. A escolaridade tem papel indireto por influenciar a qualidade institucional.

Por sua vez, Wang e Li (2017) utilizaram os dados de Tecnologias da Informação e Comunicação e de comércio bilateral do ano de 2013 a fim de analisar se as diferenças entre países em relação as TIC podem ser classificadas como fonte de vantagem comparativa no comércio internacional. Os resultados explicitam que, se o índice de desenvolvimento da TIC do país e a intensidade de $\mathrm{P} \& \mathrm{D}$ da indústria aumentar 1 desvio padrão, as exportações do país aumentam em $10 \%$. Países desenvolvidos na área da TIC têm vantagens comparativas nos setores intensivos em P\&D e setores complexos de tarefas.

De modo similar, Visser (2019) analisou o efeito da penetração da Internet, utilizando de dados referente as assinaturas de banda larga, nas margens intensivas e extensivas de exportações, além de avaliar se a Internet consegue ocupar a lacuna linguística existente no comércio internacional, no período entre 1998 a 2014. O autor trabalhou com dados em painel de 162 exportadores e 175 destinos, utilizando uma especificação do modelo de gravidade para atender aos objetivos do artigo. Os resultados apontam a associação positiva entre o aumento da penetração da Internet e as margens de exportações diferenciadas. O aumento da penetração da Internet pode diminuir a lacuna referente a distância linguística, tanto nas margens intensivas quanto nas extensivas das exportações diferenciadas. O investimento em infraestrutura em Internet pode apontar maiores benefícios marginais para países de baixa renda, indicando possível ação para os formuladores de política pública a fim de melhorar a competitividade dos exportadores.

Martínez-Zarzoso e Marquéz-Ramos (2019) avaliaram se uma melhor governança recompensa o desempenho econômico de países do Oriente Médio e Norte da África (MENA), juntamente com a integração dos mesmos na economia mundial. As deficiências instituições dos países MENA geram insegurança e déficit nas transações comerciais, entretanto, não há 
exploração entre comércio e qualidade institucional dos países. Para atingir o objetivo de análise, um modelo gravitacional estendido com indicadores de governança foi construído e estimado para os 19 países MENA, seus 189 parceiros comerciais e todos os exportadores referente ao período de 1996 a 2013, adotando a estimação pelo método de máxima verossimilhança de pseudo-poisson (PPML). Os resultados indicam que, melhorias em cinco dos seis indicadores de governança nos países de destino não afetam as exportações dos países MENA. Já considerando a amostra para todos os exportadores, os seis indicadores de governança têm impacto positivo no comércio bilateral.

Por fim, Rodríguez-Crespo e Martínez-Zarzoso (2019) utilizaram do modelo de gravidade voltado para o comércio, com intuito de analisar o efeito do uso da Internet nos fluxos agregados comerciais. Os autores trabalham com a estimação por máxima verossimilhança de pseudo-poisson (PPML), que permite capturar as resistências multilaterais variáveis no tempo (MRT) e amortecem a heterocedasticidade nos fluxos comerciais, utilizando amostra de exportações bilaterais de 120 países no período de 2000 a 2014. Os países estão segmentados de acordo com o grau de complexidade do produto. Os resultados indicam que o uso da Internet aumenta o comércio, e a segmentação por complexidade do produto é sensível ao uso da Internet, quando comparado pela segmentação por nível de renda. Países tendem a comercializar mais se há níveis semelhantes de uso das TIC associados a graus semelhantes de complexidade do produto.

Em suma, diante das evidências empíricas envolvendo comércio internacional e as TIC, nota que a análise sempre permeia dentro da utilização do modelo gravitacional, se diferenciando através dos métodos de estimação, a partir do objetivo de análise de cada autor. Há estudos que buscam estimar o modelo através de vários métodos, com intuito de analisar a consistência das estimações. Tradicionalmente, a estimação via PPML é a mais difundida dentro da literatura, justamente por apresentar alternativas para a solução de problemas com fluxo nulo de comércio e heterocedasticidade. Há estimações abordando séries temporais e outros métodos como painel GMM, por exemplo. Em relação a possíveis problemas de endogeneidade, várias aplicações trabalham com a adoção de variáveis defasadas no lugar em contrapartida as contemporâneas, outros buscam instrumentos que possam atender ao problema dentro do cenário de interesse. A estimação considerando efeitos fixos é bastante difundida dentro dos escopos empíricos, respeitando a estrutura do modelo teórico para evitar viés de variável omitida.

De modo geral, respostas envolvendo questões específicas dentro da análise de comércio internacional como a diminuição de barreiras não tarifárias são bastante superficiais e rasas. 
Entre os trabalhos apresentados, menções teóricas são realizadas, mas a abordagem analisando o efeito da penetração da Internet dentro de períodos de evolução das telecomunicações são pouco mencionadas. Grande parte das aplicações são focadas no efeito geral das variáveis de interesse no cenário das TICs dentro do comércio internacional, considerando um aspecto temporal amplo, em que diversas transformações foram submetidas no cenário das telecomunicações. Poucos trabalhos buscam trabalhar com questões específicas que fazem parte da estrutura de custos dentro do comércio internacional. A análise da sensibilidade dos resultados após a aplicação de diferentes métodos de estimação é uma evolução evidente dentro da literatura, abrindo questionamentos que necessitam ser esclarecidos dentro da aplicação do modelo e na discussão dos resultados.

Dentro dos estudos supracitados, esta dissertação analisará questões envolvendo a distância linguística e cultural que estão presentes como controle dentro do modelo gravitacional, bem como avaliará o efeito da penetração da Internet em períodos justificáveis de evolução dentro do cenário das telecomunicações, que mudaram a estrutura do setor dentro de 16 anos (2000-2016). O impacto do maior acesso à informação pode ter interferido nas configurações do comércio internacional e, consequentemente, alterar as prioridades dentro das relações entre as economias mundiais. O Quadro 1 encerra a discussão dos enfoques com o resumo de todos os estudos apresentados nessa seção referente as aplicações da TIC no comércio internacional. 
QUADRO 1 - Resumo das aplicações das TIC para o comércio internacional

\begin{tabular}{|c|c|c|c|}
\hline Autor(es) & Objetivo & Período & Contribuições \\
\hline $\begin{array}{c}\text { Freund e } \\
\text { Weinhold (2004) }\end{array}$ & $\begin{array}{l}\text { Estímulo da internet no comércio } \\
\text { internacional de } 56 \text { países. }\end{array}$ & $\begin{array}{l}1995- \\
1999\end{array}$ & $\begin{array}{c}\text { Aumento de } 10 \text { pontos percentuais no crescimento de hosts em um } \\
\text { país aumenta } 0,2 \text { pontos percentuais no crescimento das } \\
\text { exportações. }\end{array}$ \\
\hline $\begin{array}{l}\text { Fink, Matto e } \\
\text { Neagu (2005) }\end{array}$ & $\begin{array}{l}\text { Custos de comunicação como um dos } \\
\text { determinantes nos custos comerciais. }\end{array}$ & 1999 & $\begin{array}{c}\text { Custos de comunicações são mais importantes no comércio de } \\
\text { produtos diferenciados do que no comércio de produtos } \\
\text { homogêneos. }\end{array}$ \\
\hline $\begin{array}{c}\text { Clarke e } \\
\text { Wallstein (2006) }\end{array}$ & $\begin{array}{c}\text { Aumento das exportações ocorre devido ao } \\
\text { aumento da penetração da Internet ou a } \\
\text { abertura comercial incentiva o uso da } \\
\text { Internet. }\end{array}$ & 2001 & $\begin{array}{l}\text { A Internet melhora o desempenho das exportações para países em } \\
\text { desenvolvimento. O bloqueio da concorrência das } \\
\text { telecomunicações reduz a penetração da Internet e causa queda } \\
\text { para as exportações dos países mais ricos. }\end{array}$ \\
\hline Clarke (2008) & $\begin{array}{l}\text { Internet como uma das forças de impulso } \\
\text { para globalização. Correlação entre acesso à } \\
\text { Internet e desempenho das empresas de } \\
\text { países de baixa e média renda. }\end{array}$ & $\begin{array}{c}1999 \\
2002 \mathrm{e} \\
2005\end{array}$ & $\begin{array}{l}\text { Empresas conectadas à internet têm maior probabilidade de } \\
\text { exportar quando comparadas com empresas similares que não estão } \\
\text { conectadas. }\end{array}$ \\
\hline $\begin{array}{l}\text { Demirkan et al. } \\
\quad(2009)\end{array}$ & $\begin{array}{l}\text { Avaliação das TIC na redução dos custos } \\
\text { associados ao comércio internacional entre } \\
175 \text { países diferentes }\end{array}$ & 2005 & $\begin{array}{l}\text { Fluxos comerciais maiores em países com maior uso de Internet. A } \\
\text { TIC impacta mais positivamente os fluxos de economias maiores, } \\
\text { quando comparados com impacto das economias menores. } \\
\text { Melhora no comércio de países distantes entre pares de negócios. }\end{array}$ \\
\hline Choi (2010) & $\begin{array}{l}\text { Efeito da Internet nas exportações e } \\
\text { importações de serviços. }\end{array}$ & $\begin{array}{l}1990- \\
2006\end{array}$ & $\begin{array}{c}\text { Aumento de } 10 \% \text { no número de usuários da Internet por cem } \\
\text { pessoas aumentou a exportação de serviços para } 0,43 \% \text { e a } \\
\text { importação em } 0,38 \% \text {. }\end{array}$ \\
\hline Lee (2012) & $\begin{array}{l}\text { Papel das redes de Investimento Estrangeiro } \\
\text { Direto, migração e Internet no comércio } \\
\text { internacional em } 21 \text { países da OCDE. }\end{array}$ & 2008 & $\begin{array}{l}\text { Internet como canal mais importante para efeitos de rede nos } \\
\text { setores de manufatura e serviços. Migração responsável apenas } \\
\text { pelos efeitos de rede do setor manufatureiro. }\end{array}$ \\
\hline $\begin{array}{l}\text { Chung, Fleming e } \\
\text { Fleming (2013) }\end{array}$ & $\begin{array}{l}\text { TIC afetam positivamente o comércio de } \\
\text { frutas e legumes entre os países da } \\
\text { Cooperação Econômica Ásia-Pacífico } \\
\text { (APEC). }\end{array}$ & $\begin{array}{l}1997- \\
2006\end{array}$ & $\begin{array}{l}\text { Alterações nos níveis de TIC não afetam o setor de importação, } \\
\text { mas tem efeitos positivos no setor de exportação. }\end{array}$ \\
\hline Liu e Nath (2013) & $\begin{array}{l}\text { Efeito das TIC no comércio internacional } \\
\text { dos mercados emergentes. }\end{array}$ & $\begin{array}{l}1995- \\
2010\end{array}$ & $\begin{array}{l}\text { Resultados significativos e positivos referentes a assinaturas e } \\
\text { hosts de Internet no comércio internacional. É necessário o uso das } \\
\text { tecnologias, não apenas a disponibilidade ou infraestrutura. }\end{array}$ \\
\hline Dettmer (2014) & $\begin{array}{l}\text { Fuso horário como força motriz ou como } \\
\text { barreira comercial no comércio } \\
\text { internacional de serviços empresariais e } \\
\text { gerais. }\end{array}$ & $\begin{array}{l}1999- \\
2006\end{array}$ & $\begin{array}{l}\text { Fuso horário como barreira para parceiros localizados no mesmo } \\
\text { fuso, já que os fornecedores de serviços preferem lucrar com a } \\
\text { diferença do fuso horário. }\end{array}$ \\
\hline $\begin{array}{l}\text { Bankole et al. } \\
\quad(2015)\end{array}$ & $\begin{array}{c}\text { Avaliação do desdobramento da } \\
\text { infraestrutura das TIC no comércio da } \\
\text { África }\end{array}$ & $\begin{array}{l}1998- \\
2007\end{array}$ & $\begin{array}{l}\text { Infraestrutura com impacto direto no comércio e impacto indireto a } \\
\text { respeito da influência na qualidade institucional. Escolaridade tem } \\
\text { papel indireto por influenciar a qualidade institucional. }\end{array}$ \\
\hline Wang e Li (2017) & $\begin{array}{l}\text { Analisar se as diferenças em relação as TIC } \\
\text { podem ser classificadas como fonte de } \\
\text { vantagem comparativa no comércio } \\
\text { internacional. }\end{array}$ & 2013 & $\begin{array}{l}\text { Aumento do índice de desenvolvimento da TIC e intensidade de } \\
\text { P\&D em } 1 \text { desvio padrão aumenta as exportações do país em } 10 \% \text {. } \\
\text { Países desenvolvidos na área da TIC têm vantagens comparativas } \\
\text { nos setores intensivos em P\&D e complexos de tarefas. }\end{array}$ \\
\hline Visser (2019) & $\begin{array}{l}\text { Efeito da penetração da Internet nas } \\
\text { margens intensivas e extensivas de } \\
\text { exportações, além de avaliar se a Internet } \\
\text { consegue ocupar a lacuna linguística. }\end{array}$ & $\begin{array}{l}1998- \\
2014\end{array}$ & $\begin{array}{c}\text { Associação positiva entre aumento da penetração e as margens de } \\
\text { exportações diferenciadas. Aumento da penetração pode diminuir a } \\
\text { lacuna linguística. }\end{array}$ \\
\hline $\begin{array}{l}\text { Martínez-Zarzoso } \\
\text { e Marquéz-Ramos } \\
\text { (2019) }\end{array}$ & $\begin{array}{c}\text { Avaliar se a melhor governança recompensa } \\
\text { o desempenho econômico e integração } \\
\text { mundial dos países MENA }\end{array}$ & $\begin{array}{l}1996- \\
2013\end{array}$ & $\begin{array}{l}\text { Melhorias em cinco dos seis indicadores de governança nos países } \\
\text { de destino não afetam as exportações dos países MENA. Para todos } \\
\text { os exportadores, os indicadores de governança têm impacto no } \\
\text { comércio bilateral. }\end{array}$ \\
\hline $\begin{array}{l}\text { Rodríguez-Crespo } \\
\text { e Martínez- } \\
\text { Zarzoso (2019) }\end{array}$ & $\begin{array}{l}\text { Analisar o efeito do uso da Internet nos } \\
\text { fluxos agregados comerciais. }\end{array}$ & $\begin{array}{l}2000- \\
2014\end{array}$ & $\begin{array}{l}\text { Uso da Internet aumenta o comércio e a segmentação por grau de } \\
\text { complexidade do produto é sensível ao uso da Internet, quando } \\
\text { comparado com a segmentação por nível de renda. }\end{array}$ \\
\hline
\end{tabular}

Fonte: Elaboração própria. 


\section{METODOLOGIA}

A análise de informações e dados detalhados sobre políticas comerciais são necessários para a formulação de estratégias dentro dos países. Desde 1960, o modelo de comércio gravitacional tornou-se importante referência quando abordado o comércio bilateral entre países (e.g., ANDERSON; VAN WINCOOP, 2003; BERGSTRAND, 1985; CHUNG; FLEMING; FLEMING, 2013; DEARDORFF, 1997; DEMIRKAN et al., 2009; FREUND; WEINHOLD, 2000; RODRÍGUEZ-CRESPO; MARTÍNEZ-ZARZOSO, 2019; SANTOS SILVA; TENREYRO, 2006; TINBERGEN, 1962; VEMURI; SIDDIQI, 2009; VISSER, 2019; WANG; LI, 2017). O modelo de comércio gravitacional apresenta estrutura intuitiva e flexiva, integrando assim a ampla classe de modelos de equilíbrio, que podem estudar ligações entre o comércio internacional e outros fatores (e.g. meio ambiente, mercado de trabalho e investimentos) (YOTOV et al., 2016). O modelo gravitacional é originalmente derivado da ideia de Newton, ou seja, em que a atração de dois corpos celestes é proporcional ao produto das massas e apresenta relação inversa entre as distâncias entre os corpos. Como exemplo, temos as primeiras aplicações na área de economia por Ravenstein (1885) e Tinbergen (1962), que trabalharam com o modelo para resolver questões sobre imigração e fluxo de comércio, respectivamente. Os autores abordaram o modelo gravitacional sem a determinação de fundamento econômico para a aplicação, que era alvo de críticas de alguns autores pela ausência de teoria consistentes com os resultados encontrados (BERGSTRAND, 1985; HELPMAN, 1987).

Esse tipo de modelo em economia internacional gera previsões dos fluxos comerciais bilaterais a partir de fundamentos das modernas teorias do comércio de substitutos imperfeitos. Primariamente, o modelo aborda uma forma de agregação entre três variáveis que determinam as relações bilaterais do comércio: oferta do exportador, demanda do importador e os custos inclusos. A hipótese subjacente é que o comércio entre dois países é proporcional ao produto do PIB de ambas as economias, porém inversamente proporcional à distância entre as mesmas. Outras medidas de tamanho podem ser inseridas na forma de variáveis explicativas, como a área terrestre, população, além de variáveis que proporcionam medidas de proximidade cultural, como fronteiras comuns, línguas comuns, leis comuns e acordos comerciais regionais (FRANKEL; STEIN; WEI, 1997). Nessa variante de comércio internacional, Anderson (1979) foi o pioneiro e introduziu pressuposições sobre diferenciação de produtos pelo lugar de origem e as despesas constantes de elasticidade de substituição (CES) no modelo. Já Deardorff (1997) indicou a equação gravitacional pode ser derivada parcialmente pelo modelo de concorrência 
imperfeita e pelo modelo de Heckscher-Ohlin, gerando pressupostos e consistências teóricas que validaram a equação. Após os resultados apresentados por Deardorff, Frankel (1997) menciona que a possibilidade de derivação do modelo gravitacional a partir de uma variedade de teorias importantes transformou a equação gravitacional, saindo da pobreza para riqueza em termos de fundamentação teórica.

A próxima seção apresenta a estrutura teórica do modelo gravitacional na variante do comércio internacional, que, a partir dela, é derivada a equação do modelo empírico desta dissertação.

\subsection{Modelo de gravidade estrutural}

Por suposição, considera-se um mundo composto por $N$ países na estrutura teórica do modelo. Cada economia produz certa variedade de bens comercializados com o restante do mundo. A oferta de cada bem é definida como fixa em $Q_{i}$ com um preço de fabricação $p_{i}$. Dessa maneira, o valor do produto doméstico em cada país é determinado por $Y_{i}=Q_{i} p_{i}$, que corresponde a própria renda nominal do país $i\left(Y_{i}\right)$. Já as despesas agregadas do país $i$ são representadas por $E_{i}$. Elas podem ser expressas em relação a renda nominal por $E_{i}=\varphi_{i} Y_{i}$, em que $\varphi>1$ exibe que o país $i$ tem déficit comercial e $1>\varphi>0$ indica superávit fiscal. Superávits e déficits são tratados como exógenos no modelo. Para simplificar, o tempo é omitido na derivação do modelo estrutural e inicia-se a derivação pelo lado da demanda. Essa estratégia é apenas uma escolha, uma vez que o modelo pode ser originalmente obtido pelo lado da oferta (YOTOV et al., 2016).

Pelo lado da demanda, o modelo teórico assume que as preferências do consumidor são homotéticas, idênticas entre países e reproduzidas por uma função de utilidade na forma CES (constant elasticity of substitution) para cada país $j$ (YOTOV et al., 2016), ou seja:

$$
\left\{\sum_{i} \alpha_{i}^{\frac{1-\sigma}{\sigma}} c_{i j}^{\frac{\sigma-1}{\sigma}}\right\}^{\frac{\sigma}{\sigma-1}}
$$

em que $\sigma>1$ denota a elasticidade de substituição entre mercadorias de diferentes países, $\alpha_{i}>$ 0 é o parâmetro que indica a preferência da CES, tratado como exógeno, e $c_{i j}$ refere-se o consumo de mercadorias do país $i$ no país $j$. Os consumidores maximizam a função utilidade (eq. 1) sujeita à restrição orçamentária: 
$\sum_{i} p_{i j} c_{i j}=E_{J}$

Essa restrição orçamentária garante que a despesa total do país $j$ seja idêntica a despesa total em mercadorias de todas as economias mundiais, a preços de entrega representados por $p_{i j}=p_{i} t_{i j}$, definidos pelo preço de portão de fábrica no país de origem da produção, $p_{i}$, incluindo os custos comerciais bilaterais $t_{i j} \geq 1$, entre os parceiros comerciais $i$ e $j$ (YOTOV et al., 2016). Para definir as despesas com mercadorias enviadas do país $i$ ao país $j$, a otimização do consumidor assume a seguinte forma:

$$
X_{i j}=\left(\frac{\alpha_{i} p_{i} t_{i j}}{P_{j}}\right)^{(1-\sigma)} E_{j}
$$

de maneira que $X_{i j}$ representa os fluxos comerciais exportados do país $i$ para o país $j$, e $P_{j}$ denota o índice de preços ao consumidor, determinado por:

$$
P_{j}=\left[\sum_{i}\left(\alpha_{i} p_{i} t_{i j}\right)^{1-\sigma}\right]^{\frac{1}{1-\sigma}}
$$

De acordo com Yotov et al. (2016), devido à elasticidade de substituição de mercadorias $\sigma>1$ (maior que um), a equação (3) indica vários relacionamentos intuitivos, pois as despesas no país $j$ em mercadorias obtidas no país $i, X_{i j}$, são proporcionais as despesas totais, $E_{j}$ de maneira que os mercados mais ricos consomem uma maior quantidade de todas as variedades, incluindo as mercadorias do país $i$. Há uma relação inversa da equação (3) com os preços das mercadorias produzidas no país $i$ ao destino $j$, que não depende apenas do preço de fábrica $p_{i}$, mas também do custo do comércio bilateral entre parceiros, $t_{i j}$. Uma combinação ideal que favorece o comércio bilateral é uma produção eficiente, devido ao preço de fábrica e o custo do comércio bilateral serem baixos. Além disso, a equação (3) está diretamente relacionada ao preço agregado da CES, $P_{j}$, refletindo o efeito substituição entre variedades de mercadorias de países diferentes. Assim, se os bens do país $j$ são mais caros que os bens do país $i$, mais consumidores do país $j$ substituirão seu consumo para os bens do país $i$. A intensidade deste efeito de substituição, definido pela equação (3), depende, pois da própria elasticidade de substituição quando os preços das fábricas ou o preço agregado da CES mudam., isto é, uma maior elasticidade de substituição vai ampliar os efeitos de desvio do comércio das mercadorias mais caras para as mais baratas. 
Nesse sentido, a liberação do mercado para mercadorias de diferentes origens é determinada como:

$$
Y_{i}=\sum_{j}\left(\frac{\alpha_{i} p_{i} t_{i j}}{P_{j}}\right)^{(1-\sigma)} E_{j}
$$

de modo que, a preços de entrega, o valor da produção no país $i, Y_{i}$, deve ser idêntico ao gasto total com mercadorias deste país em todos os países do mundo, incluindo $i$. A partir de uma manipulação algébrica, o lado direito da equação (5) pode ser substituído pela equação (3), que define a soma de todas as remessas bilaterais de $i, Y_{i}=\sum_{j} X_{i j} \forall i$. Nesse sentido, uma vez que $Y=\sum_{i} Y_{i}$ e dividindo a equação (5) por $Y$, alcança-se:

$$
\left(\alpha_{i} p_{i}\right)^{(1-\sigma)}=\frac{\frac{Y_{i}}{Y}}{\sum_{j}\left(\frac{t_{i j}}{P_{j}}\right)^{1-\sigma} \frac{E_{j}}{Y}}
$$

Conforme Anderson e van Wincoop (2003), o termo do denominador da equação (6) pode ser definido como $\pi_{i}^{1-\sigma}=\sum_{j}\left(\frac{t_{i j}}{P_{j}}\right)^{1-\sigma} \frac{E_{j}}{Y}$. Portanto, ao substituir essa derivação dos autores, a equação (6) pode ser redefinida como:

$$
\left(\alpha_{i} p_{i}\right)^{(1-\sigma)}=\frac{\frac{Y_{i}}{Y}}{\pi_{i}^{1-\sigma}}
$$

Por fim, o termo $\left(\alpha_{i} p_{i}\right)^{(1-\sigma)}$ é, então, substituído pela definição da equação (7) nas equações (3) e (4) e, após algumas manipulações matemáticas, encontra-se o seguinte sistema de equações do modelo de gravidade estrutural:

$$
\begin{aligned}
& X_{i j}=\frac{Y_{i} E_{j}}{Y}\left(\frac{t_{i j}}{\pi_{i} P_{j}}\right)^{1-\sigma} \\
& \pi_{i}^{1-\sigma}=\sum_{j}\left(\frac{t_{i j}}{P_{j}}\right)^{1-\sigma} \frac{E_{j}}{Y} \\
& P_{j}^{1-\sigma}=\sum_{j}\left(\frac{t_{i j}}{\pi_{i}}\right)^{1-\sigma} \frac{Y_{i}}{Y}
\end{aligned}
$$

As equações (9) e (10) representam os termos de resistência multilateral externo $\pi_{i}$ e os termos de resistência multilateral interno $P_{j}$. Especialmente a equação (9) aponta a facilidade e 
dificuldade de exportação do país $i$ em relação aos seus parceiros, enquanto a equação (10) define a facilidade e dificuldade de importação do país $j$ em relação aos seus parceiros (ANDERSON; VAN WINCOOP, 2003).

Por suposição, a equação de gravidade estrutural (eq. 8) se mantém em cada período de tempo $t$, o que torna possível log-linearizar a mesma com um termo de erro $e_{i j, t}$ adicional, ou seja:

$$
\begin{gathered}
\ln X_{i j, t}=\ln E_{j, t}+\ln Y_{i, t}-\ln Y_{t}-(1-\sigma) \ln t_{i j, t}-(1-\sigma) \ln P_{j, t}-(1-\sigma) \ln \pi_{i, t} \\
+e_{i j, t}
\end{gathered}
$$

A equação (11) representa a versão mais popular e empírica da equação estrutural de gravidade aplicada. Ela tem sido utilizada para verificar diversos efeitos de diferentes determinantes no comércio internacional, como por exemplo efeitos geográficos, demográficos, tarifários, imigração, investimentos, laços culturais, megaeventos esportivos e reputação, por exemplo (YOTOV et al., 2016).

A derivação da equação (11) a partir da estrutura teórica do modelo gravitacional é a referência principal para o modelo empírico desta dissertação, que será mais bem tratado na próxima seção.

\subsection{Modelo empírico}

Para analisar o efeito da internet no comércio internacional entre as economias mundiais, especifica-se a equação básica do modelo gravitacional que será estimada econometricamente, qual seja:

$\ln X_{i j, t}=\beta_{0}+\beta_{1}$ inter $_{i j, t}+\beta_{Z} Z+u_{i}+u_{j}+u_{t}+e_{i j, t}$

em que o subscrito $i$ indica o país de origem do fluxo comercial, enquanto $j$ denota o país de destino em um determinado tempo $(t)$. Já a variável inter $_{i j t}$ representa o produto de assinaturas de banda larga por 100 pessoas entre os países $i$ e $j$. As variáveis de controle do modelo gravitacional estão inseridas no vetor $Z$. Os termos $u$ são os efeitos fixos correspondentes ao exportador, importador e ao tempo.

A estimativa do modelo gravitacional exige certa estratégia no que se concerne aos problemas que podem gerar viés e inconsistência nas estimações. A literatura aplicada indica 
caminhos a fim de contornar os possíveis problemas referente à estrutura de dados (ÁLVAREZ et al., 2018; FREUND; WEINHOLD, 2004; RODRÍGUEZ-CRESPO; MARTÍNEZZARZOSO, 2019; SANTOS SILVA; TENREYRO, 2006; VEMURI; SIDDIQI, 2009; VISSER, 2019; YOTOV et al., 2016), cujo conteúdo será abordado detalhadamente nas seções a seguir.

\subsubsection{Fluxos comerciais nulos e heterocedasticidade}

A estimação do modelo gravitacional por Mínimos Quadrados Ordinários (MQO) não considera os fluxos comerciais nulos, pois as observações são simplesmente excluídas no momento de estimação quando o fluxo de comércio é transformado para o formato log-linear (YOTOV et al., 2016). A eliminação das observações nulas dentro do fluxo comercial pode gerar o truncamento da amostra. Outro ponto a ser destacado da estimação por MQO é que ela superestima os papéis dos laços coloniais e das proximidades geográficas entre os países. Tal aspecto aponta que a desigualdade de Jensen influi nas estimativas das equações de gravidade, levando até mesmo a conclusões enganosas e distorcidas. A transformação não linear do modelo empírico na presença de heterocedasticidade apresenta estimativas severamente enviesadas, pois o valor esperado do logaritmo de uma variável aleatória é dependente dos momentos de ordem superior de sua distribuição. Com erros heterocedásticos, a transformação do erro revela correlação com as covariáveis. A transformação em log gera o truncamento da amostra, pois é incompatível com a existência de fluxos comerciais nulos (SANTOS SILVA; TENREYRO, 2006).

A desigualdade de Jensen implica que $E(\ln y) \neq \ln E(y)$, ou seja, o valor esperado do logaritmo de uma variável aleatória é diferente do logaritmo do valor esperado, havendo certa negligência no que se refere a aplicações empíricas econômicas ao desconsiderar esse problema. A prática comum de interpretar parâmetros log-lineares estimados por Mínimos Quadrados Ordinários podem gerar resultados tendenciosos, devido à presença de heterocedasticidade ${ }^{5}$ (SANTOS SILVA; TENREYRO, 2006).

\footnotetext{
${ }^{5}$ Santos Silva e Tenreyro (2006) aplicaram o teste RESET robusto à heterocedasticidade no modelo gravitacional atendendo a quatro métodos de estimação: Mínimos quadrados ordinários (MQO), Tobit, Mínimos quadrados nãolineares e Pseudo-poisson máxima verossimilhança (PPML). Para as estimações envolvendo MQO, o fluxo comercial foi abordado tendo em conta o logaritmo do fluxo sem nenhuma transformação e o logaritmo somando um para evitar a exclusão das observações com fluxo nulo no momento de estimação. Para o PPML, considerou apenas fluxos maiores que zero em uma estimação e considerando o fluxo zero na outra. Apenas os modelos envolvendo PPML passaram no teste.
} 
A estimação por Poisson com Pseudo-Máxima Verossimilhança (PPML) incorpora a questão dos fluxos comerciais nulos na estimação. Além disso, o estimador é consistente na presença de heterocedasticidade, devido à desigualdade de Jensen existentes em estimadores log-linearizados que alteram as estimativas (VISSER, 2019). O método PPML é robusto a diferentes padrões de heterocedasticidade, além de tratar naturalmente com a presença de fluxos comerciais nulos no banco de dados relativo ao comércio (SANTOS SILVA; TENREYRO, 2006). A partir de uma revisão dos estudos aplicados com modelos de gravidade, Kabir, Salim e Al-Mawali (2017) enfatizam a importância da estimação por PPML para corrigir os problemas de heterocedasticidade a fim de alcançar estimativas consistentes dos parâmetros gravitacionais.

A consistência do método PPML apresenta apenas uma única condição: a especificação correta de sua média condicional, $E\left[y_{i} \mid \mathrm{x}\right]=\exp \left(x_{i} B\right)$. Os dados não precisam seguir uma distribuição Poisson, nem $y_{i}$ ser um número inteiro para garantir um estimador consistente baseado na função de probabilidade de Poisson (SANTOS SILVA; TENREYRO, 2006).

\subsubsection{Tratamento da endogeneidade}

Como exposto por Visser (2019), as exportações podem induzir o governo a aumentar a penetração da Internet, que consequentemente aumenta o comércio, gerando, então, um possível problema de endogeneidade. A literatura aplicada sugere trabalhar com as defasagens das variáveis potencialmente endógenas ao invés do valor contemporâneo na estimação do modelo gravitacional, pois as mesmas são pré-determinadas e não são afetadas por choques ocorridos no período atual (ÁLVAREZ et al., 2018; FREUND; WEINHOLD, 2004; VEMURI; SIDDIQI, 2009)

Para resolver o problema de endogeneidade entre a Internet e as exportações, Freund e Weinold (2004) defasaram a variável responsável pela penetração da Internet em dois anos, assumindo o pressuposto de que o fluxo de exportações do ano $t$ não influenciaram as assinaturas de banda larga do ano t-2. Já Rodriguez-Crespo e Martínez-Zarzoso (2019) defasaram a variável de penetração da Internet em um ano, cuja variável, em seguida, foi ponderada com a distância entre países (i.e. interação).

Outra possível abordagem para a resolução do problema de endogeneidade é o método dos Mínimos Quadrados Generalizados de Dois Estágios (2SLS) mediante a especificação de um instrumento exógeno que possa explicar o grau de penetração da Internet em um determinando país. Visser (2019) menciona que a adoção de uma variável instrumental com a 
finalidade de resolver o problema de endogeneidade entre a penetração da Internet e o fluxo de comércio requer que ela apresente uma variação bilateral no ano sem correlação com o comércio. O autor destaca que esse tipo de variável não foi ainda devidamente encontrado por ele e nem por outras pesquisas aplicadas. Em geral, os instrumentos presentes na literatura aplicada foram julgados por Visser (2019) como ineficientes por apresentar apenas variações unilaterais ou não serem exógenos ao fluxo comercial.

\subsubsection{Termos de resistência multilateral e erro de especificação}

Os termos de resistência multilateral (MRT), variáveis no tempo, são as características não observáveis de países terceiros, tais como as políticas, tarifas e regulamentos, que podem gerar algum tipo de alteração nas relações comerciais bilaterais de países. Os efeitos exporter-time e importer-time precisam ser adicionados como efeitos fixos no modelo com intuito de controlar o efeito das resistências multilaterais não-observáveis e para evitar erro de especificação do modelo gerado pelo viés de omissão e pela inconsistência dos coeficientes de regressão, já que juntamente com os efeitos fixos de tempo, esses coeficientes pertencem a derivação teórica do modelo (ANDERSON; VAN WINCOOP, 2003; BALTAGI; EGGER; PFAFFERMAYR, 2003).

Para evitar o problema envolvendo a omissão de variáveis importantes no modelo gravitacional, uma possível solução é criar essas variáveis fictícias e incorporar dentro do painel de dados, controlando esses efeitos não-observáveis (YOTOV et al., 2016). A criação desses

efeitos fixos absorve os efeitos das variáveis variantes no tempo (e.g. o PIB). Entretanto, a presença de MRT com variação temporal gera colinearidade com variáveis de PIB e da Internet (RODRÍGUEZ-CRESPO; MARTÍNEZ-ZARZOSO, 2019). Para contornar esse problema, Martínez-Zarzoso e Márquez-Ramos (2019) adotam efeitos fixos que variam após cinco anos com objetivo de captar variação exógena, justificando que as alterações das características nãoobserváveis, como por exemplo, mudanças nas leis, políticas ou instituições não acontecem imediatamente, sendo necessário um período de implementação da mudança.

\subsection{Base de Dados}

Para avaliar o efeito da penetração da Internet como barreira não tarifária no comércio internacional a partir de um modelo gravitacional, esta dissertação conta com uma amostra de 
53 países $^{6}$ heterogêneos, sendo 14 localizados na América, 16 na Europa, 19 na Ásia, 4 na África e 1 na Oceania, para o período de 2000 à 2016. O número de países escolhidos corresponde a compatibilização entre a base de dados ideal para o estudo (26,5\% dos países presentes na base) e os controles necessários para a presente análise. O recorte temporal proposto é justificado devido a disponibilidade de dados para a Internet dentro do período analisado, no qual foram necessárias adotar defasagens temporais da variável em questão que possibilitaram a análise do objeto de estudo iniciando a partir do ano 2000 e finalizando no ano de 2016. A principal variável explicativa representa a penetração da Internet no comércio internacional e contabiliza o número de assinaturas de banda larga de um país por 100 pessoas, pois as assinaturas estão relacionadas a um conjunto mais restrito de tecnologias do que o uso da Internet, tornando a análise mais comparável ao longo do tempo com mudanças heterogêneas de tecnologias entre países. Os dados são obtidos nos World Development Indicators (WDI) do Banco Mundial. Cabe ressaltar que, conforme explanado por Visser (2019), o uso da presente variável para tratar a penetração da Internet consegue fazer referência ao uso das organizações, pois cobre tanto as assinaturas residenciais como as de organizações. O autor ressalta que a variável com maior frequência de utilização na literatura aplicada, ao reproduzir o número de usuários da Internet por 100 pessoas, não necessariamente faz referência ao uso das organizações, abrindo questionamentos acerca da real representação da variável dentro do modelo gravitacional.

Por seu turno, no conjunto das variáveis explicativas há a variável de dissimilaridade linguística, que será representada pela formulação da distância linguística. Essa variável foi proposta por Visser (2019), inspirado em Melitz e Toubal (2014), que constroem a medida de proximidade linguística por meio de variáveis que conseguem indicar semelhanças linguísticas entre países. O autor atua na inversão das semelhanças linguísticas presentes na literatura aplicada a fim de criar a distância linguística e inserir a mesma no modelo gravitacional. A construção da variável está representada no Apêndice A. A justificativa é que a atuação de apenas uma medida de linguagem comum, que geralmente é adotada como dicotômica, que indica se há ou não linguagem comum entre países, não é suficiente para abordar a influência da linguagem no comércio internacional. Além disso, a utilização dessa variável binária

\footnotetext{
${ }^{6}$ (i) Américas: Argentina, Bolívia, Brasil, Canadá, Chile, Colômbia, Equador, Estados Unidos, México, Jamaica, Panamá, Paraguai, Peru, Uruguai; (ii) Europa: Alemanha, Bélgica, Dinamarca, Espanha, Finlândia, França, Itália, Holanda, Noruega, Polônia, Portugal, Reino Unido, República Dominicana, Suécia, Suíça; (iii) Ásia: Arábia Saudita, Bahrein, Catar, China, Cingapura, Coreia do Sul, Emirados Árabes Unidos, Filipinas, Hong Kong, Índia, Indonésia, Israel, Japão, Malásia, Omã, Rússia, Tailândia, Turquia, Vietnã; (iv) África: África do Sul, Argélia, Egito, Marrocos; (v) Oceania: Austrália.
} 
subestimaria o efeito da linguagem comum dentro do modelo gravitacional, conforme aponta Melitz e Toubal (2014).

Já os fluxos de comércio bilateral são valorados por Free On Board (FOB) e pertencem ao banco de dados da Base Analytique du Commerce Internacional (BACI) do Centre d'Etudes Prospectives et d'Informations (CEPII) para os anos 2000-2016. A base de dados disponibiliza os fluxos internacionais entre países, não contando com os fluxos intranacionais. Os valores estão representados em de US\$ bilhões correntes do ano de 2018 para todos os países analisados. A base trabalha com os dados brutos pertencentes a COMTRADE (UNITED NATIONS, 2021), conciliando as declarações entre exportador e importador, que podem ser diferentes no momento de declaração. O fluxo de países é harmonizado diante da eliminação dos custos CIF (Cost, Insurance and Freight) para a obtenção das importações FOB de todos os países, o que consequentemente reproduz fluxos idênticos de exportação e importação entre os pares de países. Os dados advindos do COMTRADE e do CEPII estão presentes em vários estudos dentro da literatura empírica (CLARKE; WALLSTEN, 2006; OSNAGO; TAN, 2016; RODRÍGUEZ-CRESPO; MARTÍNEZ-ZARZOSO, 2019; VISSER, 2019; WANG; LI, 2017), além de ser possível de obter informações desagregadas por produto para análises setoriais, por exemplo.

A base de dados é citada por Yotov et al. (2016) no guia avançado de análise de política comercial do World Trade Organization como recomendado para estudos envolvendo fluxos comerciais, através da metodologia gravitacional. A base de dados da CEPII resolve desafios presentes nas modelagens envolvendo o comércio internacional, pois compatibiliza os fluxos do importador e exportador, elimina os custos CIF envolvidos nas importações, identifica os fluxos de comércio nulos entre países, resolvendo questionamentos acerca de dados faltantes, presentes nos dados brutos da COMTRADE. Toda essa manutenção desenvolvida pela base de dados trás confiabilidade nos resultados estimados via modelo gravitacional, já que o trabalho envolvendo os dados brutos podem trazer questionamentos envolvendo todos os processos descritos acima. Estudos que abordam apenas o lado das exportações e importações podem apresentar resultados subestimados ou superestimados, devido às imprecisões presentes nos dados relatados na plataforma COMTRADE.

Como alternativa, esta dissertação adota a base de dados International Trade and Production Database for Estimation (ITPD-E), que contém dados consistentes de comércio internacional e doméstico para 243 países, 170 setores econômicos durante 17 anos. Por conveniência, as atividades setoriais foram agregadas em cinco grandes setores, quais sejam: agricultura, mineração, energia, manufatura e serviços entre os anos de 2000 até 2016. Essa 
base de dados tem a vantagem de ser adequada para estimativas, pois possui uma cobertura detalhada e abrangente das setores produtivos, assim como compreende um número maior de países (BORCHERT et al., 2020). Diferente do banco de dados da BACII, os dados da ITPDE permite estimar os efeitos do setor de serviços devido à disponibilidade do fluxo comercial. É possível comparar as estimações obtidas por ambas as bases e verificar a consistência e estabilidade dos resultados alcançados, especialmente dentro do mesmo recorte temporal próximo.

As variáveis de controle do modelo gravitacional advêm do Centre d'Etudes Prospectives et d'Informations (CEPII), como: (i) distância geográfica ponderada pela participação da maior cidade no total da população do país (em quilômetros); (ii) PIB dos países exportadores e importadores; (iii) variável dicotômica se há ou não a presença de relação colonial entre ambos os países; (iv) variável dicotômica se existe a presença contiguidade entre as economias internacionais; (v) diferença em relação ao fuso horário; (vi) variável índice que denota o grau de religião comum entre países; (vii) variável dicotômica que indica se os países foram colonizados pelo mesmo colonizador ou não; e (viii) outra variável dicotômica se as moedas são idênticas ou não entre ao países. Para o controle dos acordos regionais do comércio, os dados foram obtidos da base de dados Mario Larch's Regional Trade Agreements (EGGER; LARCH, 2008), que disponibiliza todos os acordos comerciais multilaterais e bilaterais que foram notificados a Organização Mundial do Comércio de 1950 a 2019.

Os controles gravitacionais buscam manter a consistência teórica dentro da adoção empírica, tanto que é visualizado em grande parte das aplicações empíricas envolvendo o modelo gravitacional. Por exemplo, as variáveis tradicionais do modelo gravitacional como: distância geográfica, PIB, relação colonial, contiguidade, colonizador comum e moeda idêntica seguem Sousa (2012), Santos Silva e Tenreyro (2006), Yotov et al. (2016), Osnago e Tan (2016) e Visser (2019). O índice que denota o grau de religião comum entre países segue Disdier e Mayer (2007). Para a diferença em relação ao fuso horário, a referência está no estudo de Egger e Larch (2013).

O Quadro 2 sumaria a descrição das variáveis que serão utilizadas no modelo gravitacional, juntamente com o sinal esperado e a fonte referente à coleta dos dados. 
QUADRO 2 - Descrição das variáveis

\begin{tabular}{|cllll|}
\hline Variável & \multicolumn{1}{c}{ Descrição } & \multicolumn{1}{c}{ Unidade } & $\begin{array}{c}\text { Sinal } \\
\text { esperado }\end{array}$ & \multicolumn{1}{c|}{ Fonte } \\
\hline $\mathrm{Y}$ & Fluxo comercial FOB & US\$ bilhão & \multicolumn{2}{c|}{ BACI - CEPII } \\
$\mathrm{D}_{1}$ & Fronteira comum & Dicotômica & + & CEPII \\
$\mathrm{X}_{1}$ & distância geográfica & Quilômetro & - & CEPII \\
$\mathrm{D}_{2}$ & Colônia do país parceiro & Dicotômica & + & CEPII \\
$\mathrm{D}_{3}$ & Acordo Regional de Comércio & Dicotômica & + & Mario Larch's RTA \\
$\mathrm{X}_{2}$ & Diferença de fuso horário & Horas & - & CEPII \\
$\mathrm{X}_{3}$ & Religião comum entre países & Escala $(0-1)$ & + & CEPII \\
$\mathrm{X}_{4}$ & Distância linguística & Escala $(0-1)$ & - & Melitz e Toubal (2014) \\
$\mathrm{D}_{4}$ & Moeda comum entre países & Dicotômica & + & CEPII \\
$\mathrm{D}_{5}$ & Colonizador comum & Dicotômica & + & CEPII \\
$\mathrm{X}_{6}$ & Produto Interno Bruto do país & US\$ bilhão & + & CEPII \\
$\mathrm{X}_{7}$ & assinatura de banda larga por 100 & Número de & + & WDI - BANCO \\
& pessoas & pessoas & & MUNDIAL \\
\hline
\end{tabular}

Fonte: Elaboração própria.

Os sinais esperados para cada variável seguem os estudos aplicados que abordaram o modelo gravitacional para o comércio internacional, tendo em vista os controles padrões estabelecidos nos estudos aplicados sobre o tema e a abordagem assumindo a penetração da Internet no comércio (EGGER; LARCH, 2013; MARTÍNEZ-ZARZOSO; MÁRQUEZRAMOS, 2019; RODRÍGUEZ-CRESPO; MARTÍNEZ-ZARZOSO, 2019; SANTOS SILVA; TENREYRO, 2006; VISSER, 2019). Um alto nível do PIB no país indica alto nível de produção e, portanto, aumenta a disponibilidade de bens para o mercado exportador de cada país. Para os países importadores, um elevado nível de PIB no país importador sugere importações elevadas. Já para a distância geográfica, a expectativa é de que o sinal seja negativo, já que atua como uma referência para todas as fontes de custo de comércio possíveis. Ou seja, a maior magnitude da variável indica maiores custos comerciais, como por exemplo, custos de transporte, que gera impactos significativos no fluxo comercial entre países.

Para as variáveis dicotômicas, que explicitam relações entre países como fronteira comum, colônia do país parceiro, acordo regional do comércio e colonizador comum, a expectativa é que todas elas apresentem sinais positivos. A questão da fronteira comum traz facilitações a respeito do frete dos produtos, além de compartilhar relações que são geradas através da proximidade, gerando ganhos comerciais que aumentam o fluxo comercial. A relação colonial entre países envolve toda a concepção histórica de formação da colônia, que abrem 
relações entre eles que impactam positivamente no fluxo comercial. Acordos regionais de comércio são elaborados com intuito de facilitação comercial entre os membros, com foco no ganho de privilégios dentro do cenário do comércio internacional. O compartilhamento de colonizador comum gera características semelhantes entre as colônias que possibilitam relações que impactam no comércio, além de trazer facilidades quando comparado com países que estão distantes dentro de características linguísticas, por exemplo.

É esperado um sinal positivo na relação entre religião e comércio internacional, ou seja, é esperado que quanto maior o grau de religião comum entre eles beneficie positivamente o fluxo comercial. Tendo em conta a distância linguística, espera-se que o sinal seja negativo, uma vez que é a mesma reproduz para dissimilaridade linguística, ou seja, quando mais distantes em relação linguística, pior os resultados em relação ao fluxo comercial de ambos. Do mesmo modo, espera-se um sinal positivo do coeficiente estimado da variável de penetração da Internet, o que significa apontar que quanto maior a penetração da informação e comunicação dentro do país, maior será o impacto positivo no mercado internacional entre países, pois há a possibilidade do aumento da interação e negociação entre ambas as partes, além da diminuição dos custos de informação.

A Tabela 1 exibe as estatísticas descritivas das variáveis contínuas da base de dados, quais sejam: fluxo das exportações, distância geográfica, diferença de fuso horário, distância linguística, PIB e assinatura de banda larga por 100 pessoas.

TABELA 1 - Estatísticas descritivas das variáveis quantitativas do banco de dados (2000 - 2016)

\begin{tabular}{lcccc}
\hline \multicolumn{1}{c}{ Indicadores } & Média & $\begin{array}{c}\text { Desvio } \\
\text { Padrão }\end{array}$ & Mínimo & Máximo \\
\hline Fluxo comercial FOB (por bilhões de dólares) & 3,40 & 13,89 & 0 & 420,14 \\
Distância geográfica (quilômetros) & $8.376,63$ & $4.816,14$ & 131,76 & $19.650,13$ \\
Diferença de fuso horário (horas) & 5,17 & 3,48 & 0 & 12 \\
Distância linguística & 0,78 & 0,21 & 0 & 1 \\
PIB (por bilhões de dólares) & 985,13 & 2239,17 & 6,32 & $18.707,19$ \\
Assinatura de banda larga (por 100 pessoas) & 11,74 & 12,53 & 0 & 45,03 \\
\hline Fonte: Elaboração própria. & & & &
\end{tabular}

O fluxo comercial FOB dos 53 países heterogêneos expõe fluxo médio entre pares de 3,40 bilhões de dólares, com valor máximo de 420,14 bilhões de dólares. A distância geográfica exibe, em média, 8.376,63 quilômetros entre pares, sendo a menor distância entre países de 
131,76 quilômetros e a maior, 19.650,13 quilômetros. A diferença de fuso horário, em média, foi de 5,17 horas. A distância linguística entre países apresenta, em média, valor contínuo de 0,78, mostrando evidências que a amostra trabalha com países com maior diferença linguística dentro da análise. O PIB apresentou valor médio de US\$ 985,13 bilhões, sendo o país mais pobre em termos de PIB da amostra o Paraguai, com valor de US\$ 6,32 bilhões para o ano de 2002, e o país mais rico em termos de PIB os Estados Unidos, com valor de US\$ 18.707,19 bilhões para o ano de 2016. Em média, os países da amostra possuem 11,74 pessoas a cada 100 com assinaturas de banda larga dentro do período de análise.

Do ponto de vista técnico, a International Telecommunications Union (ITU) classifica o desenvolvimento da comunicação móvel pelo sistema IMT (International Mobile Telecommunications). As especificações IMT-2000 foram desenvolvidas por 15 anos (1985 2000) e ficou vigente como único sistema de comunicação móvel até o ano de 2012, em que foi adotada as especificações IMT-Advanced, que foram desenvolvidas desde 2003. A partir de 2015, as especificações IMT-2020 começaram a serem desenvolvidas, com previsão de adoção para o ano de 2020 (ITU, 2015).

Do ponto de vista de mercado, as comunicações móveis são divididas por gerações. A segunda geração $(2 \mathrm{G})$ possui como característica a mudança para uma plataforma digital na rede de acesso de rádio, a introdução da troca de pacotes, acessibilidade a serviços de voz e de mensagens de texto e a conectividade de dados de qualidade aceitável. A terceira geração $(3 \mathrm{G})$ tratou na combinação das tecnologias de comutação de voz e dados, gerando novas tecnologias de acesso ao rádio, harmonização de espectro, maior alocação de espectro para a comunicação móvel, além da harmonização de padrões estabelecidos pela ITU, gerando padrões comuns para comunicação móvel através de diferentes consórcios. Como destaque, evidencia a capacidade de conectividade de rede para serviços multimídias, todos baseados nas especificações IMT2000. A quarta geração $(4 \mathrm{G})$ é diretamente proporcional às tecnologias que trabalham com as especificações IMT-Advanced. Ela é caracterizada pela centralização de dados e baseada em tecnologia com pacotes puros sem voz comutada por circuito. Apresentam novas tecnologias de acesso de rádio, além de arquitetura plana de rede que diminui a latência da internet. $\mathrm{O}$ rendimento é muito alto, já que as larguras de banda são de amplo espectro, com tecnologias de modulação eficientes e antenas estruturadas. Em consequência, o alto rendimento das redes torna a tecnologia móvel competitiva quando comparado com a banda larga fixa (TADAYONI; HENTEN; SØRENSEN, 2018).

O ideal dentro da análise seria capturar os efeitos das mudanças tecnológicas no comércio internacional mediante a adoção de recortes temporais em relação a períodos que caracterizam 
essas mudanças. Popular desde os anos 90, a evolução das tecnologias móveis gerou um aumento da eficiência e da produtividade do setor das telecomunicações (LAM; SHIU, 2010). Entretanto, o número de observações contidas dentro dos intervalos de tempos que caracterizam as gerações móveis possui graus de liberdade distintos e, consequentemente, impossibilita a variabilidade dos dados dentro do painel de dados. Outro fator está relacionado a adoção de intervalos temporais com intuito de corrigir a colinearidade entre os MRT com as variáveis de PIB e Internet, que só seria possível para a análise de uma geração de tecnologia móvel dentro do período adotado. 


\section{ANÁLISE DOS RESULTADOS}

Para apresentar os efeitos estimados da Internet sobre o comércio internacional entre os países em estágios distintos de desenvolvimento, a estratégia deste capítulo é apresentar as estimativas em duas etapas sucessivas. A primeira etapa fornecerá as estimativas das variáveis selecionadas contra o fluxo de comércio sem discriminá-lo por grande atividade econômica. Essa seção apresentará ainda as estimativas de setores primários e secundários a fim de completar a discussão do fluxo geral de comércio exterior.

Em seguida, a segunda etapa abordará as estimativas do comércio de cada setor econômico, justamente para obter um refinamento de como o comércio de cada setor é influenciado pela Internet no período. Nessa segunda etapa, espera-se que as respostas sejam distintas, uma vez que o padrão da pauta de comércio exterior é diferente entre os países da amostra, especialmente entre aqueles classificados como desenvolvidos e os em desenvolvimentos. Por exemplo, em geral, os produtos manufaturados de países desenvolvidos apresentam uma participação relativamente maior na pauta exportadora do que a de um país em desenvolvimento, que é caracterizada por uma presença maior de produtos primários e tradicionais. Por fim, como as exportações de serviços são intangíveis, mas mais intensiva no uso de serviços de informação, a relação das variáveis selecionadas com este tipo de comércio apresenta provavelmente uma dinâmica de comércio exterior diferente se comparada com a da agropecuária e da indústria.

\subsection{Efeitos estimados sobre o fluxo geral de comércio exterior}

Com todos os 53 países dentro do painel de dados, há 2.756 pares de países interagindo via comércio internacional dentro do período de análise. Todas as estimações adotam o erropadrão robusto à heterocedasticidade, já que os modelos estimados via Mínimos Quadrados Ordinários exibem a presença de heterocedasticidade controlados pelos testes Breusch-Pagan e White rejeitando a hipótese nula de variância constante. O modelo PPML incorpora a robustez em relação a heterocedasticidade em sua estimação.

O teste de Breusch-Pagan-Godfrey e o teste de White têm como função detectar a presença da heterocedasticidade nas estimações. O primeiro atua após a obtenção dos resíduos das estimações, em seguida calculando a variância do erro por meio do estimador de máxima verossimilhança. Após essa etapa, são construídas variáveis determinadas pelo resíduo ao quadrado divido pela variância do erro calculada. De posse dessas variáveis, regride sobre as 
variáveis independentes do modelo, obtendo a soma dos quadrados explicados, que determina uma estatística que segue distribuição qui-quadrado com (m-1) graus de liberdade após a multiplicação por $1 / 2$. Se a estatística calculada for maior que o valor crítico que segue a distribuição qui-quadrado, rejeita-se a hipótese de homoscedasticidade. O teste de BreuschPagan- Godfrey não necessita do número de observações centrais omitidas, nem da ordenação dos valores das variáveis omitidas, atuando como um teste geral para detecção de heterocedasticidade. Já o teste de White não requer hipótese de normalidade e conta com fácil implementação. Após a obtenção dos resíduos estimados, adota-se regressões dos mesmos ao quadrado contra os originais, seus valores elevados ao quadrado e os produtos cruzados dos regressores, podendo também incluir os regressores com expoentes mais altos. Após a estimação, é obtido o $\mathrm{R}^{2}$ dessa regressão, que multiplicado tamanho da amostra gera estatística que segue assintoticamente a distribuição qui-quadrado com graus de liberdade iguais ao número de regressores da equação construída. Se a estatística qui-quadrado obtida excede o valor crítico ao nível escolhido de significância, rejeita-se a hipótese nula de que não há heterocedasticidade (GUJARATI; PORTER, 2008).

A Tabela 2 reporta os resultados para o painel de dados contínuo do modelo gravitacional para o período 2000-2016, considerando os modelos estimados com e sem efeitos fixos, a fim de comparar as mudanças e avaliar a consistência dos resultados. Os métodos adotados para estimação são: Mínimos Quadrados Ordinários (MQO) e Pseudo-poisson de Máxima Verossimilhança (PPML). 
TABELA 2 - Resultados estimados do modelo gravitacional por quatro métodos de estimação (2000 - 2016)

\begin{tabular}{|c|c|c|c|c|}
\hline \multirow{3}{*}{ Descrição da variável } & \multicolumn{4}{|c|}{ Variável dependente: Fluxo comercial FOB } \\
\hline & (1) & (2) & (3) & (4) \\
\hline & MQO & MQO & PPML & PPML \\
\hline \multirow{2}{*}{ Acordo regional de comércio } & $0,408^{* * *}$ & $0,349^{* * *}$ & 0,111 & $0,277^{* * *}$ \\
\hline & $(0,087)$ & $(0,108)$ & $(0,070)$ & $(0,064)$ \\
\hline \multirow{2}{*}{ Distância geográfica (log) } & $-0,748^{* * *}$ & $-0,946^{* * *}$ & $-0,380^{* * *}$ & $-0,541^{* * *}$ \\
\hline & $(0,080)$ & $(0,099)$ & $(0,070)$ & $(0,051)$ \\
\hline \multirow{2}{*}{ Colônia do país parceiro } & $0,374^{* * *}$ & $0,512^{* * *}$ & $-0,181^{*}$ & $-0,001$ \\
\hline & $(0,133)$ & $(0,149)$ & $(0,105)$ & $(0,091)$ \\
\hline \multirow{2}{*}{ Fronteira comum } & $0,895^{* * *}$ & $0,388^{* *}$ & $0,774^{* * *}$ & $0,551^{* * *}$ \\
\hline & $(0,180)$ & $(0,188)$ & $(0,121)$ & $(0,071)$ \\
\hline \multirow{2}{*}{ Diferença de fuso horário } & $-0,025$ & $-0,055^{* * *}$ & $-0,063^{* * *}$ & $-0,037^{* * *}$ \\
\hline & $(0,016)$ & $(0,016)$ & $(0,018)$ & $(0,012)$ \\
\hline \multirow{2}{*}{ Religião comum } & $1,189^{* * *}$ & $1,654^{* * *}$ & $-1,000^{* * *}$ & $0,218^{*}$ \\
\hline & $(0,204)$ & $(0,201)$ & $(0,300)$ & $(0,126)$ \\
\hline \multirow{2}{*}{ Colonizador comum } & $-0,424$ & $-0,630$ & $1,069^{* * *}$ & $0,377^{*}$ \\
\hline & $(0,507)$ & $(0,435)$ & $(0,228)$ & $(0,203)$ \\
\hline \multirow{2}{*}{ Distância linguística } & $1,137^{* * *}$ & $0,939^{* * *}$ & $-0,677^{* *}$ & 0,127 \\
\hline & $(0,287)$ & $(0,329)$ & $(0,335)$ & $(0,144)$ \\
\hline \multirow{2}{*}{ Moeda comum } & $-0,409^{* *}$ & $-0,959^{* * *}$ & 0,151 & 0,035 \\
\hline & $(0,173)$ & $(0,160)$ & $(0,101)$ & $(0,091)$ \\
\hline \multirow{2}{*}{ Produto do PIB (log) } & $1,177^{* * *}$ & $1,084^{* * *}$ & $0,761^{* * *}$ & $0,738^{* * *}$ \\
\hline & $(0,027)$ & $(0,072)$ & $(0,026)$ & $(0,035)$ \\
\hline \multirow{2}{*}{ Produto das assinaturas de banda larga $(\log )_{(\mathrm{t}-2)}$} & $-0,006^{* * *}$ & $-0,024^{* * *}$ & $-0,004^{* *}$ & $0,008^{* *}$ \\
\hline & $(0,001)$ & $(0,007)$ & $(0,001)$ & $(0,003)$ \\
\hline \multirow{2}{*}{ Constante } & $-36,795^{* * *}$ & $-31,981^{* * *}$ & $-22,366^{* * *}$ & $-20,603^{* * *}$ \\
\hline & $(1,334)$ & $(3,150)$ & $(1,094)$ & $(1,509)$ \\
\hline$N$ & 46750 & 46750 & 46750 & 46750 \\
\hline Importer-time & Não & $\operatorname{Sim}$ & Não & $\mathrm{Sim}$ \\
\hline Exporter-time & Não & Sim & Não & Sim \\
\hline $\mathrm{R}^{2}$ & 0,540 & 0,672 & 0,716 & 0,911 \\
\hline
\end{tabular}

Fonte: Resultados da pesquisa.

Nota: Erro padrão em parênteses; ${ }^{*} p<0,10 ;{ }^{* *} p<, 05 ;{ }^{* * *} p<, 01$.

Para a principal variável de análise, produto das assinaturas de banda larga, o modelo (4) estimado por PPML com efeitos fixos variantes no tempo para o exportador e importador, exibe que o efeito da duplicação das assinaturas entre pares de países parceiros, ceteris paribus, geraria aumento do fluxo comercial em $0,80 \%$. O resultado estimado por PPML sugere que o aumento das assinaturas de banda larga pode diminuir os custos fixos e variáveis e aumentar o fluxo comercial entre os países. Embora o impacto das variáveis de internet seja pequeno na 
visão agregada, quando comparado com outros controles presentes na modelagem gravitacional, a variável de Internet não depende de qualquer tipo de relação histórica entre países ou de acordos envolvendo questões políticas, pois se trata de uma questão maleável que pode ser facilmente manipulável (LIN, 2015; VISSER, 2019). Osnago e Tan (2016) apontam que a maior adoção da Internet permite que o exportador encontre mais compradores para seus produtos, aumentando a gama de produtos exportados, consequentemente, gerando maior fluxo comercial entre países.

A inclusão dos termos de resistência multilateral (MRT) como efeitos fixos para absorção das variações variáveis no tempo, como foi discutido no capítulo metodológico, podem gerar colinearidade com as variáveis responsáveis pela Internet e pelo Produto Interno Bruto (PIB). Juntamente a isso, a introdução de intervalos deve ser empregue com intuito de permitir o ajuste nos fluxos de comércio bilaterais em razão à resposta de política comercial ou de mudanças nos custos comerciais. Intervalos de três, quatro ou cinco anos entregam resultados semelhantes em relação às estimativas levando em conta o painel completo (YOTOV et al., 2016). Assim, a estimativa pelos modelos gravitacionais procede a partir de intervalos de quatro anos para que os efeitos fixos consigam captar possíveis variações exógenas que possam influenciar nas estimações. A Tabela 3 reporta os resultados da Equação (12) para o fluxo comercial (em US\$ milhão) de 53 países com características distintas, para o período 2000-2016, com intervalos temporais de quatro anos. Os métodos adotados para estimação são: Mínimos Quadrados Ordinários (MQO) e Pseudo-poisson de Máxima Verossimilhança (PPML).

Após o controle proposto, os resultados para o produto das assinaturas de banda larga entre países retratam coeficientes próximos ao estimado pelo painel completo, no qual o choque que ocasionaria a duplicação da rede de assinaturas de banda larga entre países, ceteris paribus, geraria o aumento do fluxo comercial de $0,70 \%$. Em relação aos acordos regionais de comércio, a magnitude dos três modelos apresenta semelhança e significância estatística. Para o modelo (3), estimado via PPML e controlado pelos efeitos fixos variantes no tempo do exportador e importador, o coeficiente obtido implica que os acordos regionais de comércio que entraram em vigor dentro do período de 2000 à 2016, em média, aumentaram o comércio em 33,43\%. Visser (2019) apresenta que, para as exportações diferenciadas entre 1998 e 2014, os acordos aumentaram em média $41,05 \%$ do fluxo comercial. Já para as margens extensivas e intensivas, o aumento no fluxo comercial foi de $11,07 \%$ e $30,21 \%$, respectivamente. 
TABELA 3 - Resultados estimados com intervalo temporal de quatro anos (2000 - 2016)

\begin{tabular}{|c|c|c|c|}
\hline \multirow{3}{*}{ Descrição da variável } & \multicolumn{3}{|c|}{ Variável dependente: Fluxo comercial FOB } \\
\hline & (1) & $(2)$ & (3) \\
\hline & MQO & MQO & PPML \\
\hline \multirow{2}{*}{ Acordo regional de comércio } & $0,398^{* * *}$ & $0,324^{* * *}$ & $0,288^{* * *}$ \\
\hline & $(0,094)$ & $(0,115)$ & $(0,061)$ \\
\hline \multirow{2}{*}{ Distância geográfica (log) } & $-0,741^{* * *}$ & $-0,938^{* * *}$ & $-0,531^{* * *}$ \\
\hline & $(0,085)$ & $(0,109)$ & $(0,050)$ \\
\hline \multirow{2}{*}{ Colônia do país parceiro } & $0,399^{* * *}$ & $0,542^{* * *}$ & 0,007 \\
\hline & $(0,138)$ & $(0,156)$ & $(0,090)$ \\
\hline \multirow{2}{*}{ Fronteira comum } & $0,904^{* * *}$ & $0,405^{* *}$ & $0,548^{* * *}$ \\
\hline & $(0,190)$ & $(0,203)$ & $(0,069)$ \\
\hline \multirow{2}{*}{ Diferença de fuso horário } & $-0,027$ & $-0,061^{* * *}$ & $-0,038^{* * *}$ \\
\hline & $(0,017)$ & $(0,017)$ & $(0,011)$ \\
\hline \multirow{2}{*}{ Religião comum } & $1,278^{* * *}$ & $1,793^{* * *}$ & $0,223^{*}$ \\
\hline & $(0,212)$ & $(0,215)$ & $(0,125)$ \\
\hline \multirow{2}{*}{ Colonizador comum } & $-0,554$ & $-0,734$ & $0,372^{*}$ \\
\hline & $(0,553)$ & $(0,483)$ & $(0,203)$ \\
\hline \multirow{2}{*}{ Distância linguística } & $1,250^{* * *}$ & $1,096^{* * *}$ & 0,125 \\
\hline & $(0,302)$ & $(0,349)$ & $(0,141)$ \\
\hline \multirow{2}{*}{ Moeda comum } & $-0,389^{* *}$ & $-1,052^{* * *}$ & 0,039 \\
\hline & $(0,193)$ & $(0,168)$ & $(0,087)$ \\
\hline \multirow{2}{*}{ Produto do PIB (log) } & $1,213^{* * *}$ & $1,129^{* * *}$ & $0,738^{* * *}$ \\
\hline & $(0,030)$ & $(0,078)$ & $(0,034)$ \\
\hline \multirow{2}{*}{$\begin{array}{l}\text { Produto das assinaturas de banda larga } \\
(\log )_{(t-2)}\end{array}$} & $-0,007^{* * *}$ & $-0,028^{* * *}$ & $0,007^{* *}$ \\
\hline & $(0,002)$ & $(0,008)$ & $(0,003)$ \\
\hline \multirow{2}{*}{ Constante } & $-38,233^{* * *}$ & $-33,991^{* * *}$ & $-20,780^{* * *}$ \\
\hline & $(1,376)$ & $(3,378)$ & $(1,459)$ \\
\hline$N$ & 13750 & 13750 & 13750 \\
\hline Exporter-time & Não & Sim & Sim \\
\hline Importer-time & Não & $\operatorname{Sim}$ & Sim \\
\hline $\mathrm{R}^{2}$ & 0,524 & 0,658 & 0,913 \\
\hline
\end{tabular}

Fonte: Resultados da pesquisa.

Nota: Erro padrão robusto em parênteses; ${ }^{*} p<0,10 ;{ }^{* *} p<, 05 ;{ }^{* * *} p<.01$.

A variável responsável pela distância linguística foi estatisticamente significativa a 1\% para ambos os modelos estimados por MQO, porém com sinal positivo diferente do estudo de Visser (2019), no qual é esperado que o aumento da distância linguística entre pares de países gere uma diminuição do comércio exterior entre países. Os resultados não convergem com as estimações realizadas por Visser (2019), que encontra a relação inversa entre a distância linguística e o fluxo comercial para todas as estimações via MQO, considerando as exportações diferenciadas e margens intensivas e extensivas do comércio internacional. A divergência pode 
estar relacionada devido à abordagem agregada que contempla todos os produtos comercializados entre os países dentro do período, que após a separação em setores, pode exibir a influência da distância linguística.

Por seu turno, a variável de distância euclidiana geográfica em quilômetros entre países os três modelos exibem coeficientes significativos. Pelo modelo PPML, por exemplo, o coeficiente estimado para essa variável sinaliza que a cada $10 \%$ de aumento da distância geográfica entre pares de países que realizam comércio, ceteris paribus, é esperado a queda de $5,31 \%$ do fluxo comercial entre eles. Esse ponto corrobora com a relação inversa em que países mais distantes tendem a negociar menos em relação a países próximos. Para resultados obtidos via PPML nos estudos aplicados que dialogam com os resultados alcançados, Osnago e Tan (2016) encontram coeficiente estimado de -0,869 para a distância geográfica, em que o choque de $10 \%$ de aumento da distância entre pares de países que realizam comércio gera uma diminuição de 8,69\% no fluxo comercial entre eles. Para os resultados de Visser (2019), o mesmo choque para as margens extensivas implica na diminuição de 6,21\% do fluxo comercial e de 5,37\% no fluxo comercial das margens intensivas. Em suma, uma vez que a distância geográfica é atribuída como uma referência de todas as fontes de custo de comércio inseridas representa a relação de comércio internacional, quanto maior essa barreira geográfica entre países, maior são os custos de comércio, desestímulando o comércio se comparado com possibilidades de comércio com países menos distantes (menor custo de comércio). Outro ponto de observação é que altos custos de comércio acompanham nas tomadas de decisões das empresas, dado que altos custos de comércio podem gerar decisões de investimento em outras localidades, com intuito de maximizar os ganhos da empresa.

As demais variáveis que são indicadoras de desenvolvimento das TICs foram testadas nas estimações, como as assinaturas de celulares e telefones, porém ambas apresentam problemas de colinearidade com variáveis importantes do modelo, como o PIB, e baixa significância nas estimações. O melhor desempenho dentre as variáveis foi a de assinatura de banda larga. Outra variável evidenciada na literatura para mensurar o efeito da Internet no comércio internacional (e.g. LIN, 2015; VEMURI; SIDDIQI, 2009) corresponde ao número de usuários de Internet no país disponível no Banco Mundial, porém a informação estatística não possui atualizações desde o ano de 2012, e sua disponibilidade está presente somente na base de dados de backup da organização. Para contornar a colinearidade do PIB e da Internet com os efeitos fixos inseridos no modelo gravitacional, a variação temporal de quatro anos dentro do painel de 
dados, não solucionaram o problema. Entretanto, os testes não indicam a presença de multicolinearidade entre as principais variáveis explicativas do modelo gravitacional ${ }^{7}$.

Com o intuito de avaliar se há diferenças entre as características que influenciam o fluxo comercial de diferentes produtos entre países, a amostra foi dividida entre setor primário (produtos animais, vegetais e minerais) e secundário (produtos das indústrias químicas, plástico, borracha, alimentos preparados, peles, couros, obras de madeira, papel, têxteis, calçado, guarda chuva, obras de pedra, gesso, metal base, máquinas e aparelhos mecânicos, instrumentos e aparelhos de óptica, armas, munições e manufaturas diversas). A Tabela 4 apresenta os coeficientes estimados pelo modelo gravitacional estimados a partir do método PPML para ambos os setores dentro do período de análise. Para o setor primário, cabe destacar a influência da distância geográfica no fluxo comercial entre países, apontando sinal esperado que dialoga com as referências aplicadas, significativo a $1 \%$ e, quando comparado com o coeficiente do setor secundário, exibe aproximadamente o dobro de influência na explicação do fluxo comercial entre países. Ou seja, a cada 10\% de aumento da distância geográfica entre países parceiros no mercado do setor primário, espera uma queda de $11,16 \%$ no fluxo comercial entre eles.

Já para o setor secundário, tendo em mente o mesmo choque, a queda no fluxo comercial seria de 5,05\%. Como evidenciado por Borchert e Yotov (2017), na análise do comércio internacional de manufaturas para 69 países, em média, o efeito da distância geográfica no comércio internacional diminuiu ao longo do tempo, dentro do período de 1986 à 2006, provavelmente através dos impactos das novas tecnologias ou da fragmentação produtiva, o que explicaria o menor impacto da distância no setor secundário, mais intensivo em produção industrial, quando comparado com o setor primário. Outro ponto levantado pelos autores é de que a distância geográfica não perdeu força para vários países de baixa renda, colocando em risco a integração aos mercados globais. Para confirmação das evidências, busca analisar os resultados dos grandes setores da economia, que tornam o nível de desagregação do fluxo comercial maior.

\footnotetext{
${ }^{7} \mathrm{O}$ fator VIF, que estima o aumento da variância para a regressão de MQO, apresentou em média o fator de 1,76 considerando todas as variáveis independentes do modelo gravitacional. Individualmente, nenhuma das variáveis apresenta fator VIF maior que 5, que indicaria a presença de multicolinearidade.
} 
TABELA 4 - Estimativas pelo método PPML para os setores primários e secundários no comércio exterior (2000 - 2016)

\begin{tabular}{|c|c|c|}
\hline \multirow{3}{*}{ Descrição da variável } & \multicolumn{2}{|c|}{ Variável dependente: Fluxo comercial FOB } \\
\hline & (1) & $(2)$ \\
\hline & Setor primário & Setor secundário \\
\hline \multirow{2}{*}{ Acordo regional de comércio } & 0,153 & $0,327^{* * *}$ \\
\hline & $(0,130)$ & $(0,052)$ \\
\hline \multirow{2}{*}{ Distância geográfica (log) } & $-1,116^{* * *}$ & $-0,505^{* * *}$ \\
\hline & $(0,111)$ & $(0,047)$ \\
\hline \multirow{2}{*}{ Colônia do país parceiro } & $-0,018$ & 0,047 \\
\hline & $(0,199)$ & $(0,088)$ \\
\hline \multirow{2}{*}{ Fronteira comum } & $0,426^{* * *}$ & $0,504^{* * *}$ \\
\hline & $(0,148)$ & $(0,066)$ \\
\hline \multirow{2}{*}{ Diferença de fuso horário } & 0,013 & $-0,040^{* * *}$ \\
\hline & $(0,025)$ & $(0,010)$ \\
\hline \multirow{2}{*}{ Religião comum } & $-0,711^{* *}$ & $0,513^{* * *}$ \\
\hline & $(0,282)$ & $(0,111)$ \\
\hline \multirow{2}{*}{ Colonizador comum } & 0,344 & $0,388^{* *}$ \\
\hline & $(0,350)$ & $(0,184)$ \\
\hline \multirow{2}{*}{ Distância linguística } & $-0,947^{* *}$ & $0,235^{* *}$ \\
\hline & $(0,372)$ & $(0,117)$ \\
\hline \multirow{2}{*}{ Moeda comum } & $-0,224$ & 0,085 \\
\hline & $(0,233)$ & $(0,077)$ \\
\hline \multirow{2}{*}{ Produto do PIB (log) } & $0,556^{* * *}$ & $0,778^{* * *}$ \\
\hline & $(0,040)$ & $(0,038)$ \\
\hline \multirow{2}{*}{ Produto das assinaturas de banda larga $(\log )_{(t-2)}$} & $0,053^{* * *}$ & 0,004 \\
\hline & $(0,007)$ & $(0,004)$ \\
\hline \multirow{2}{*}{ Constante } & $-10,546^{* * *}$ & $-22,844^{* * *}$ \\
\hline & $(1,857)$ & $(1,653)$ \\
\hline$N$ & 13750 & 13750 \\
\hline Exporter-time & Sim & $\operatorname{Sim}$ \\
\hline Importer-time & $\operatorname{Sim}$ & $\operatorname{Sim}$ \\
\hline $\mathrm{R}^{2}$ & 0,734 & 0,945 \\
\hline
\end{tabular}

Fonte: Resultados da pesquisa.

Erro padrão robusto em parênteses; ${ }^{*} p<0,10 ;{ }^{* *} p<, 05 ;{ }^{* * *} p<, 01$.

Em relação ao produto das assinaturas de banda larga entre os países, o impacto da internet no setor primário foi maior que o impacto da amostra como um todo. Ou seja, ao duplicar o número de assinaturas de banda larga entre países parceiros teve-se provavelmente um aumento de 5,30\% no fluxo comercial. Os resultados para o setor secundário não foram estatisticamente significativos. O efeito da Internet na diminuição do custo comercial para o setor foi maior que o encontrado para a amostra agregada, mostrando que o investimento nas 
redes de assinatura entre países pode ser uma importante abordagem para países dependentes do setor primário, já que expõe ganho elevado de fluxo comercial para o setor.

Todavia, como mencionado por Osnago e Tan (2016), a maior adoção de acesso à Internet em um país exportador pode reduzir as exportações de bens homogêneos por serem menos intensivos em informação, devido à negociação por meio da bolsa de valores ou por causa dos preços de referência.

A variável de distância linguística é medida em uma escala contínua de 0 até 1 . Para os resultados estimados para o setor primário, o aumento de 0,1 unidade na escala de distância linguística, ceteris paribus, acarretaria uma diminuição média de 9,47\% no fluxo comercial entre países. Como mencionado por Melitz e Toubal (2014), a facilidade de comunicação dentro do comércio de bens homogêneos auxilia na compreensão dos problemas, já que a habilidade linguística nunca é irrelevante ao comércio. Mercadorias podem atrasar ou danificar, contratos podem não ser honrados, além da necessidade de recorrer a clausuras de contrato. Os autores sugerem que, de modo geral, as empresas podem expandir seu comércio exterior na medida em que investe em mão de obra qualificada em línguas estrangeiras. Em relação ao setor secundário, a distância linguística não exibe a relação esperada, dado que o aumento da distância linguística entre países, em média, ocasionaria o aumento do fluxo comercial. Melitz e Toubal (2014) dentro da análise dos fatores linguísticos no comércio bilateral entre 1998 à 2007, encontram coeficientes com maior magnitude para bens diferenciados quando comparado com os de bens homogêneos $(1,237$ contra 0,676$)$ em relação a variável de proximidade linguística. Visser (2019) não encontra relação positiva entre a distância linguística e as margens intensivas e extensivas do comércio, juntamente com as exportações de bens diferenciados.

\subsection{Efeitos estimados sobre o fluxo setorial de comércio exterior}

Essa seção apresenta as estimativas por quatro de tipo de atividade econômica, cuja classificação é uma agregação derivada do banco de dados da ITPD-. A Tabela 5 reporta os resultados estimativos no modelo gravitacional pelo método com efeitos fixos sobre o fluxo setorial de comércio exterior para os anos de 2000 até 2016, levando ainda em conta intervalos de quatro anos entre os períodos dentro do painel de dados.

O produto das assinaturas de banda larga entre pares de países para os grandes setores da agricultura, manufatura e serviços não apresentaram coeficientes significativos. Já para os grandes setores de energia e mineração, a aplicação do choque que duplica as redes de 
assinaturas de banda larga entre pares de países provocaria um aumento do fluxo comercial dos setores de 7,10\%. Em relação à distância linguística, o ganho de 0,1 unidade na escala de distância linguística, ceteris paribus, provocaria uma diminuição média de 10,98 \% no fluxo comercial dos grandes setores de energia e mineração. Para o grande setor de agricultura, os resultados foram diferentes, uma vez que o mesmo choque geraria em média o aumento no fluxo comercial do grande setor de 10,94\%, não acompanhando os resultados discutidos para a Tabela 4.

O efeito da distância geográfica para o grande setor de manufatura transmite relação negativa com o fluxo comercial, além de menor magnitude quando comparado com os resultados obtidos para os grandes setores da agricultura, energia e mineração. Para o choque de $10 \%$ no aumento da distância geográfica entre pares de países que realizam comércio a diminuição de $6,38 \%$ no fluxo comercial do grande setor de manufatura é esperada. O mesmo choque para o grande setor de agricultura ocasiona a diminuição de $10,40 \%$ no fluxo comercial e para os grandes setores de energia e mineração o impacto gerado diminui o fluxo comercial para 15,26\%. Como discutido na Tabela 4, o efeito da distância geográfica para o comércio das manufaturas diminuiu ao longo do tempo, consequentemente, gerando impacto em todos os custos comerciais envolvidos, que podem ser explicados pela fragmentação produtiva e na intensidade de novas tecnologias no setor. O setor de produtos diferenciados está alinhado a intensidade produtiva e informacional, absorvendo assim as tecnologias desenvolvidas dentro do cenário mundial.

Já o setor de produtos homogêneos não se beneficia tanto desses fatores que diminuem os custos comerciais, que é evidenciado pela magnitude da distância geográfica dentro dos respectivos grandes setores da agricultura, energia e mineração. Outra colocação se deve ao fato de que o padrão da pauta de comércio exterior distinto entre os países da amostra pode influenciar nos resultados encontrados, devido ao impacto relativamente maior dos produtos manufaturados na balança comercial dos países desenvolvidos, comparado com os países em desenvolvimento, que refletem na magnitude dos custos comerciais inseridos dentro de cada grande setor da economia. 
TABELA 5 - Estimativas pelo método PPML sobre o fluxo setorial de comércio exterior com intervalo de quatro anos (2000 - 2016)

\begin{tabular}{|c|c|c|c|c|}
\hline \multirow{3}{*}{ Descrição da variável } & \multicolumn{4}{|c|}{ Variável dependente: Fluxo comercial FOB } \\
\hline & (1) & (2) & (3) & (4) \\
\hline & Agricultura & Energia e Mineração & Manufatura & Serviços \\
\hline \multirow{2}{*}{ Acordo regional de comércio } & $0,188^{*}$ & 0,078 & $0,260^{* * *}$ & 0,427 \\
\hline & $(0,103)$ & $(0,166)$ & $(0,055)$ & $(-)$ \\
\hline \multirow{2}{*}{ Distância geográfica (log) } & $-1,040^{* * *}$ & $-1,526^{* * *}$ & $-0,638^{* * *}$ & $-0,449$ \\
\hline & $(0,117)$ & $(0,173)$ & $(0,048)$ & $(-)$ \\
\hline \multirow{2}{*}{ Colônia do país parceiro } & 0,072 & 0,293 & $-0,009$ & 0,235 \\
\hline & $(0,217)$ & $(0,260)$ & $(0,091)$ & $(-)$ \\
\hline \multirow{2}{*}{ Fronteira comum } & $0,383^{* * *}$ & $0,582^{* * *}$ & $0,329^{* * *}$ & 0,217 \\
\hline & $(0,132)$ & $(0,211)$ & $(0,066)$ & $(-)$ \\
\hline \multirow{2}{*}{ Diferença de fuso horário } & 0,015 & $0,057^{*}$ & $-0,021^{* *}$ & $-0,014$ \\
\hline & $(0,029)$ & $(0,033)$ & $(0,010)$ & $(-)$ \\
\hline \multirow{2}{*}{ Religião comum } & $0,490^{* *}$ & $-0,726^{*}$ & $0,378^{* * *}$ & 0,960 \\
\hline & $(0,245)$ & $(0,418)$ & $(0,117)$ & $(-)$ \\
\hline \multirow{2}{*}{ Colonizador comum } & 0,356 & 0,147 & $0,297^{*}$ & $-0,090$ \\
\hline & $(0,271)$ & $(0,380)$ & $(0,156)$ & $(-)$ \\
\hline \multirow{2}{*}{ Distância linguística } & $1,094^{* * *}$ & $-1,098^{* *}$ & 0,176 & $-0,309$ \\
\hline & $(0,279)$ & $(0,556)$ & $(0,134)$ & $(-)$ \\
\hline \multirow{2}{*}{ Moeda comum } & $0,453^{* * *}$ & $-0,867^{* *}$ & 0,038 & $-0,142$ \\
\hline & $(0,161)$ & $(0,418)$ & $(0,077)$ & $(-)$ \\
\hline \multirow{2}{*}{ Produto do PIB (log) } & $1,104^{* * *}$ & $1,015^{* * *}$ & $0,803^{* * *}$ & 4,379 \\
\hline & $(0,071)$ & $(0,087)$ & $(0,052)$ & $(-)$ \\
\hline \multirow{2}{*}{$\begin{array}{l}\text { Produto das assinaturas de banda larga } \\
(\log )_{(t-2)}\end{array}$} & 0,005 & $0,071^{* * *}$ & 0,001 & 0,000 \\
\hline & $(0,020)$ & $(0,019)$ & $(0,005)$ & $(-)$ \\
\hline \multirow{2}{*}{ Constante } & $-29,585^{* * *}$ & $-19,590^{* * *}$ & $-15,701^{* * *}$ & $-143,314$ \\
\hline & $(2,976)$ & $(3,489)$ & $(2,193)$ & $(-)$ \\
\hline$N$ & 12860 & 12495 & 13230 & 5951 \\
\hline Exporter-time & $\operatorname{Sim}$ & Sim & $\operatorname{Sim}$ & Sim \\
\hline Importer-time & Sim & $\operatorname{Sim}$ & $\operatorname{Sim}$ & Sim \\
\hline $\mathrm{R}^{2}$ & 0,777 & 0,791 & 0,941 & 0,898 \\
\hline
\end{tabular}

Fonte: Resultados da pesquisa.

Erro padrão robusto em parênteses; ${ }^{*} p<0,10 ;{ }^{* *} p<, 05 ;{ }^{* * *} p<, 01$.

A amostra para o grande setor de serviços exibe número de observações menores que outros setores explicitados anteriormente. A dificuldade de se obter o fluxo comercial do setor de serviços é evidenciada nas principais bases de dados que trabalham com o comércio internacional, tanto que é exposto a dificuldade de obter dados sobre o comércio bilateral de serviços, devido à limitação do mesmo. Entre as justificativas, aborda a dificuldade de registrar com segurança os fluxos comerciais de serviços intangíveis e não armazenáveis (BORCHERT 
et al., 2020). Para o modelo estimado, a matriz de variância foi altamente singular, indicando alta correlação entre as variáveis. Consequentemente, não há estimadores únicos para o modelo do grande setor de serviços. ${ }^{8}$

Os resultados estimados por meio da amostra desenvolvida pelo ITPD-E são questionáveis, ainda mais pela falta de observações dentro dos quatro grandes setores apresentados. As conclusões obtidas por meio dos fluxos comerciais a partir da base de dados BACII tratam do problema dos dados faltantes dentro da amostra, já o ITPD-E faz algumas ponderações a respeito dos fluxos nulos. Não há informações concretas de que os missings se tratam de fluxos comerciais nulos ou dados faltantes. Com isso, há impossibilidade de comparar os setores em relação ao desempenho das assinaturas de Internet no comércio internacional.

Em suma, as estimativas pelo método PPML contêm evidências robustas que podem refletir o verdadeiro efeito dos controles estabelecidos dentro dos fluxos comerciais, sejam eles agregados ou tratados por via setorial. O modelo PPML não gera questionamentos em relação aos fluxos nulos do comércio, já que para as estimações por Mínimos Quadrados Ordinários é necessário o incremento de uma constante marginal para evitar o truncamento da amostra, que podem gerar magnitudes que não representam o real efeito dos controles inseridos na estimação do fluxo comercial entre pares de países. O resultado do fluxo agregado entrega evidências de que a Internet influencia a redução dos custos associados ao comércio internacional. Por se tratar de uma característica maleável que não depende de relações históricas e acordos comerciais de outros países, entra como oportunidade de investimento o aumento das redes de assinaturas de banda larga com possíveis parceiros, pois o estímulo no fluxo comercial pode melhorar as condições econômicas de países de baixa renda. Para o setor primário, o impacto da Internet no fluxo comercial foi maior, porém abre questionamentos acerca das discussões que envolvem a mudança na pauta de comércio exterior de produtos. A maior intensidade de informações gerada pelas redes de Internet pode ocasionar a preferência por bens diferenciados, em detrimento dos bens homogêneos, presentes em boa parte do setor primário, em que seus preços são determinados pela bolsa de valores ou seguem preço de referência.

A análise da distância geográfica dentro do modelo gravitacional transparece a relação no qual os bens manufaturados estão em constante benefício do processo de globalização, pois comparativamente o efeito dela para o setor secundário e para o grande setor de manufaturas é menor que quando comparados com o setor primário e os grandes setores inseridos na estrutura.

\footnotetext{
${ }^{8} \mathrm{O}$ Fator VIF para as variáveis independentes do modelo indicam em média o valor de 1,72, apontando indícios que não há a presença de colinearidade entre as variáveis. A colinearidade está relacionada com os efeitos fixos do importador e exportador.
} 
Não obstante, as evidências empíricas não entregam a atuação das redes de Internet entre países dentro do comércio que envolve as manufaturas, que são ferramentas propícias para a inserção de informações e que permitem o processo de difusão tecnológica e compartilhamento de conhecimento. Entretanto, a magnitude baixa encontrada para os fluxos agregados expõe que diferentes interações do e-commerce e da difusão de informações para o setor secundário podem ser esperadas. Os grandes setores da agricultura e manufatura não revelaram resultados que permitem estatisticamente afirmar o impacto da expansão da Internet no fluxo comercial de países. Já para o grande setor de serviços, a alta colinearidade dos dados não permitiu que a análise fosse realizada por PPML.

Por fim, as estimativas desta pesquisa apontaram que a variável de distância linguística não apresentou relações esperadas dentro da literatura aplicada para o setor primário dentro do período de 2000 à 2016. Tais estimativas sinalizam que eventuais restrições geradas pela distância linguística podem ser contornadas via comércio digital, talvez, pela disponibilidade de profissionais capacitados em língua estrangeira. Essa discussão sugere hipóteses no qual a ampla troca de informações com clareza linguística pode acarretar o desenvolvimento de relações entre empresas, evitando possíveis problemas e distanciamentos que possam gerar o fim do comércio entre eles. 


\section{CONSIDERAÇÕES FINAIS}

As transformações no comércio internacional geraram uma maior integração produtiva e comercial entre países, inclusão de economias em nichos de mercados especializados, ampliação da escala de produção, economias de escala de empresas internacionais e fragmentação das cadeias de suplementos ou de insumos intermediários. Dentro desse panorama, o surgimento da Internet a partir da década de 90, junto com a propagação da globalização, propulsionaram a disseminação das TICs (Tecnologia da Informação e Comunicação) nos setores e nações, que podem proporcionar maior fluxo de informações com intuito de interromper barreiras de entrada ao mercado, com a diminuição dos custos atrelados ao comércio. Diante disso, a dissertação ofereceu contribuição acerca dos efeitos da Internet no comércio internacional que abrange 53 países em distintos estágios de desenvolvimento. A estratégia de análise consiste em avaliar o efeito da Internet no período entre 2000 e 2016, com ênfase no fluxo comercial agregados dos países, juntamente com os efeitos desagregados para os setores da economia.

A hipótese é que a penetração da Internet, juntamente com a evolução tecnológica das telecomunicações, gerou a diminuição dos custos comerciais, o que, consequentemente, influenciou positivamente no fluxo comercial entre os países, diminuindo o efeito das barreiras comerciais entre países, sejam elas referentes a questão linguística, cultural ou informacional, que podem influenciar nos custos fixos e variáveis do comércio. Além disso, a análise se estende por detalhar as influências que as tecnologias de informação e comunicação incidem dentro do comércio internacional, que, por vezes, podem ser induzidas mediante os esforços individuais dos países. Avaliar o efeito das outras variáveis determinantes dentro do recorte temporal e da desagregação setorial contribui para entender o provável caminho pelo qual a evolução das telecomunicações conduz os fluxos comerciais entre países.

Os resultados estimados para o fluxo comercial agregado obtidos por meio da estimação por PPML, que em grande parte das aplicações do estudo apontam evidências de boa especificação do modelo, exibe impacto de $0,80 \%$ no aumento do fluxo comercial, ao dobrar as redes de assinaturas de banda larga entre pares de países que possuem relações comerciais. O controle das estimações tendo em vista intervalos de tempo de quatro anos, com intuito de corrigir problemas de colinearidade do PIB e da Internet com os efeitos fixos do importador e exportador variantes no tempo, que foram inclusos para captar as variações exógenas que impactam nas estimações, produzem um impacto menor para o mesmo choque, aumento de $0,70 \%$ no fluxo comercial entre países da amostra. Apesar de apontar impacto pequeno quando 
comparados com outros controles tradicionais do modelo gravitacional, as redes de assinaturas e de banda larga não dependem de nenhum tipo de relação histórica ou política entre países, já que pode advir de um instrumento de política pública no qual o país interessado esteja disposto em expandir suas redes de Internet. Essa colocação abre outros tipos de reflexão no qual as intervenções pelo aumento podem atuar de diversas vertentes, sejam elas públicas ou privadas, abrindo a questão da autonomia do país em decidir em qual cenário a evolução da Internet apontaria resultados melhores para a evolução comercial.

$\mathrm{Na}$ análise para os setores primário e secundário, o choque para a duplicação das assinaturas de banda larga, levando em consideração redes entre países parceiros de negócio, gerariam aumento de 5,30\% no fluxo comercial do setor primário, não apontando resultados estatisticamente significativos para o setor secundário. $\mathrm{O}$ ganho de comércio aponta um possível instrumento para países dependentes das exportações de bens pertencentes ao setor primário (de sua maioria bens homogêneos). Entretanto, a alta adoção de Internet dentro de um país pode influenciar a inversão produtiva do país, já que a alta intensidade de informações tende a gerar a diminuição da exportação de bens homogêneos, que ostentam preços tabelados e definidos pela bolsa de valores. Em relação à distância linguística, o setor primário pode investir na diminuição da mesma, dado que o aumento da distância entre países em 0,1 , ocasionaria a diminuição de 9,47\% no fluxo comercial do setor. Além disso, a presença de funcionários capacitados em língua estrangeira facilita a resolução de problemas que podem estar inseridos nas relações entre empresas e países, juntamente com a diminuição do risco de existir quebras de relações devido à dificuldade comunicativa entre eles. Pode apontar uma importante característica de estímulo ao comércio entre países distintos.

A distância geográfica entre países, utilizada como referência para todos os custos comerciais, entrega evidências em relação aos grandes setores da economia de que a distância incide efeitos menores no fluxo comerciais de bens manufaturados, graças a adoção tecnológica e a fragmentação produtiva, quando comparados com outros setores com predominância de bens homogêneos, como os grandes setores da agricultura, energia e mineração. Ou seja, o grande setor de manufaturas consegue absorver melhor os avanços tecnológicos, refletindo na redução dos custos comerciais que impactam fortemente no fluxo comercial entre países, dado que as elasticidades encontradas são relativamente menores quando comparados com os outros grandes setores da agricultura e da energia e mineração (-0,638 contra -1,040 e -1,526).

Portanto, as implicações políticas desses resultados são diretas. As evidências mostram que investimentos na ampliação da rede de banda larga do país tende a gerar ganhos comerciais, principalmente para os bens homogêneos. Acordos comerciais em prol do desenvolvimento de 
redes de Internet tendem a ocasionar efeitos no aumento do fluxo comercial, como por exemplo, parcerias para o desenvolvimento das telecomunicações com objetivo de se obter novas tecnologias de informação e comunicação, como o 5G. A confiabilidade gerada ao apoiar em acordos desse tipo poderia gerar o fortalecimento de laços entre países que tendem a viabilizar diversas linhas de progressão, desde a cooperação para avanço tecnológico até ao estabelecimento de instituições e empresas que tendem a gerar produtos diferenciados que colaboram positivamente na balança comercial. Levando em consideração o grau de expansão das redes de assinatura, há a possibilidade de transição da pauta exportadora dos países de bens homogêneos para bens intensivos em informação, de modo que a ampliação pode seguir caminhos de crescimento e desenvolvimento econômico diferentes que no fim favorecem positivamente o ganho de capital do país. Ou seja, o mercado pode ficar ainda mais dependente das exportações de bens homogêneos ou desenvolver incentivos para a instalação de fábricas estrangeiras e nacionais, graças a intensidade de informações que diminui a incerteza nas decisões e facilita o acesso ao país devido ao ambiente web. Há também a possibilidade da criação de capacitação linguística avançada no ensino médio, que podem ocasionar a disponibilidade de profissionais que tendem a facilitar a resolução dos problemas relacionados ao comércio bilateral entre países, devido à dificuldade de especialização de alguns profissionais dentro de países pobres, que diminuem a inserção ao mundo globalizado.

A limitação do estudo se dá a indisponibilidade de dados para o grande setor de serviços, que poderiam expor impactos e discussões sobre o ambiente online e a inserção plena do setor. O desenvolvimento dos dados para o grande setor acima de países heterogêneos localizados em diversas posições continentais pode contribuir em referência a encontrar efeitos da inserção das tecnologias de informação e comunicação para o caso em questão. A hipótese para o setor é que a Internet possibilitou diversas interações de mercado que caminham em direções opostas as atividades tradicionais inseridas no comércio internacional, dado que o desenvolvimento do e-commerce e a possibilidade de fluxo de serviços online para outros países abre novas possibilidades de ganho comercial. Países podem se pautar na exportação de serviços como forma de obter vantagem econômica, na falta de recursos naturais para a provisão de bens homogêneos ou na falta de intensidade produtiva e capital para a provisão de bens diferenciados.

A falta de instrumentos para a correção da endogeneidade entre a variável de Internet e fluxo comercial também merece destaque, já que a defasagem da variável de interesse pode não corrigir perfeitamente o problema. Reflexões acerca da obtenção de um bom instrumento que consiga cobrir as especificidades envolvendo os fluxos comerciais entre os países e as 
assinaturas de Internet torna um exercício de evolução dentro das aplicações do modelo gravitacional, já que a tarefa de sugerir um instrumento com variabilidade mútua entre países e que mantenha as relações esperadas têm suas dificuldades e pode gerar resultados que estabelecem a relação de causa e efeito do desenvolvimento das redes de Internet no comércio internacional. Os desenvolvimentos metodológicos apresentados na dissertação podem ocasionar avanços e extensões, dado que abre o pressuposto para a obtenção de análises dentro do cenário de aplicabilidade das TICs como fator de incentivo ao comércio, devido ao seu papel na redução dos custos.

As estimações por PPML abrem caminhos para a implementação de análises com equilíbrio geral, ao obter as elasticidades que impactam o fluxo comercial entre países, não deixando de controlar os efeitos fixos variantes no tempo do exportador e importador. Com posse das elasticidades calculadas, há a possibilidade de choques em um ambiente de equilíbrio, devido a interdependência entre as entidades econômicas presentes no sistema de comércio, com objetivo de analisar especificadamente políticas públicas e comerciais que tendem a impactar o comércio internacional. Como sugestão para trabalhos futuros, cabe a exploração da heterogeneidade espacial da infraestrutura de comunicação relacionado com o fluxo comercial entre países. 


\section{REFERÊNCIAS}

ABELIANSKY, A. L.; HILBERT, M. Digital technology and international trade: Is it the quantity of subscriptions or the quality of data speed that matters? Telecommunications Policy, v. 41, n. 1, p. 35-48, 1 fev. 2017.

ÁLVAREZ, I. C. et al. Does Institutional Quality Matter for Trade? Institutional Conditions in a Sectoral Trade Framework. World Development, v. 103, p. 72-87, 1 mar. 2018.

ANDERSON, J. E. A Theoretical Foundation for the Gravity Equation. American Economic Review, 1979.

ANDERSON, J. E.; VAN WINCOOP, E. Gravity with gravitas: A solution to the border puzzle. American Economic Review, v. 93, n. 1, p. 170-192, mar. 2003.

ANDERSON, J. E.; VAN WINCOOP, E. Trade costs. Journal of Economic Literature, v. 42, n. 3, p. 691-751, set. 2004.

ATHREYE, S.; CANTWELL, J. Creating competition? Globalization and the emergence of new technology producers. Research Policy, v. 36, n. 2, p. 209-226, 2007.

BALTAGI, B. H.; EGGER, P.; PFAFFERMAYR, M. A generalized design for bilateral trade flow models. Economics Letters, v. 80, n. 3, p. 391-397, 1 set. 2003.

BANKOLE, F. O.; OSEI-BRYSON, K. M.; BROWN, I. The Impact of Information and Communications Technology Infrastructure and Complementary Factors on Intra-African Trade. Information Technology for Development, v. 21, n. 1, p. 12-28, 2 jan. 2015. Disponível em: <http://www.tandfonline.com/doi/full/10.1080/02681102.2013.832128>. Acesso em: 12 mar. 2020.

BERGSTRAND, J. H. The Gravity Equation in International Trade: Some Microeconomic Foundations and Empirical Evidence. The Review of Economics and Statistics, v. 67, n. 3, p. 474, ago. 1985.

BORCHERT, I. et al. The International Trade and Production Database for Estimation (ITPDE). International Economics, 24 ago. 2020.

BORCHERT, I.; YOTOV, Y. V. Distance, globalization, and international trade. Economics Letters, v. 153, p. 32-38, 1 abr. 2017.

BUTTON, K. Transport Economics. 3rd Edition, Edward Elgar Publishing, 2010. Disponível em: <https://econpapers.repec.org/RePEc:elg:eebook:1863>.

CÉSAR, G. R. C. A agenda da "integração profunda" e nosso "Acordo do Século XXI". PONTES - Informações e Análises sobre Comércio Sustentável, v. 9, n. 8, p. 8-12, 2013.

CHOI, C. The effect of the Internet on service trade. Economics Letters, v. 109, n. 2, p. 102104, 1 nov. 2010. 
CHUNG, K. C.; FLEMING, P.; FLEMING, E. The impact of information and communication technology on international trade in fruit and vegetables in APEC. Asian-Pacific Economic Literature, v. 27, n. 2, p. 117-130, 1 nov. 2013. Disponível em: $<$ http://doi.wiley.com/10.1111/apel.12028>. Acesso em: 25 mar. 2020.

CLARKE, G. R. G. Has the internet increased exports for firms from low and middle-income countries? Information Economics and Policy, v. 20, n. 1, p. 16-37, 1 mar. 2008.

CLARKE, G. R. G.; WALLSTEN, S. J. Has the Internet Increased Trade? Developed and Developing Country Evidence. Economic Inquiry, v. 44, n. 3, p. 465-484, 1 jul. 2006.

COLECCHIA, A.; SCHREYER, P. ICT investment and economic growth in the 1990s: Is the United States a unique case? Review of Economic Dynamics, v. 5, n. 2, p. 408-442, 2002.

COMBES, P.-P.; MAYER, T.; THISSE, J.-F. Economic Geography: The Integration of Regions and Nations. Princeton University Press, 416 p., 2008. Disponível em: $<$ http://www.jstor.org/stable/j.ctvem4h9k.6>.

CYRUS, T. L. Cultural distance and bilateral trade. Global Economy Journal, v. 12, n. 4, 17 nov. 2012.

DEARDORFF, A.; STERN, R. Measurement of Non-Tariff Barriers. OECD Economics Department Working Papers, v. 179, p. 1-117, 1997. Disponível em: $<$ https://doi.org/10.1787/568705648470>.

DEARDORFF, A. V. Determinants of Bilateral Trade: Does Gravity Work in a Neoclassical World? In: FRANKEL, J. A. (Org.). The Regionalization of the World Economy. University of Chicago Press, 1997.

DEMIRKAN, H. et al. Does Distance Matter? The Influence of ICT on Bilateral Trade Flows. GlobDev 2009, 14 dez. 2009. Disponível em: <https://aisel.aisnet.org/globdev2009/17>. Acesso em: 12 maio 2020.

DETTMER, B. International Service Transactions: Is Time a Trade Barrier in a Connected World? International Economic Journal, v. 28, n. 2, p. 225-254, 2014.

DISDIER, A. C.; MAYER, T. Je t'aime, moi non plus: Bilateral opinions and international trade. European Journal of Political Economy, v. 23, n. 4, p. 1140-1159, 1 dez. 2007.

EGGER, P. H.; LARCH, M. Time zone differences as trade barriers. Economics Letters, v. 119, n. 2, p. 172-175, 1 maio 2013.

EGGER, P.; LARCH, M. Interdependent preferential trade agreement memberships: An empirical analysis. Journal of International Economics, v. 76, n. 2, p. 384-399, 1 dez. 2008.

FERNANDEZ, R. Returns to Regionalism: An Evaluation of Non-Traditional Gains from RTAs. NBER Working Papers, 1997. Disponível em: $<$ https://ideas.repec.org/p/nbr/nberwo/5970.html>. Acesso em: 1 out. 2020. 
FGV. Cadeias Globais de Valor. EESP CCGI - Centro do Comércio Global e Investimento. Disponível em: < https://ccgi.fgv.br/pt-br/cadeias-globais-de-valor>. Acesso em: 5 out. 2020.

FINK, C.; MATTOO, A.; NEAGU, I. C. Assessing the impact of communication costs on international trade. Journal of International Economics, v. 67, n. 2, p. 428-445, 1 dez. 2005.

FRANK, A. G.; DALENOGARE, L. S.; AYALA, N. F. Industry 4.0 technologies: Implementation patterns in manufacturing companies. International Journal of Production Economics, v. 210, p. 15-26, 1 abr. 2019.

FRANKEL, J. A.; STEIN, E.; WEI, S. J. The gravity model of bilateral trade. Regional trading blocks in the world economic system, v. 1946, p. 49-74, 1997.

FRANKEL, J. A. The Regionalization of the World Economy. University of Chicago Press, 1997.

FREUND, C. L.; WEINHOLD, D. An Empirical Investigation of the Internet International Trade: The Case of Bolivia. Working papers: Instituto de Investigaciones Socio-Económicas. Universidad Católica Boliviana, 2000.

FREUND, C. L.; WEINHOLD, D. The effect of the Internet on international trade. Journal of International Economics, v. 62, n. 1, p. 171-189, 1 jan. 2004.

FREUND, C.; ROCHA, N. What constrains Africa's exports? The World Bank economic review, v. 25, n. 3 (2011), p. 361-386, 30 maio 2011.

FRIEDMAN, T. L. The Lexus and the Olive Tree: Understanding Globalization. New York: Farrar, Straus and Giroux, 1999.

GUJARATI, D. N.; PORTER, D. C. Basic Econometrics. McGraw-Hill Publishing, 2008. Disponível em: <https://books.google.com.br/books?id=UauUCgAAQBAJ>.

GURBAXANI, V.; WHANG, S. The Impact of Information Systems on Organizations and Markets. Communications of the ACM, v. 34, n. 1, p. 59-73, 1 mar. 1991.

HARVEY, D. A condição pós-moderna. Loyola ed. São Paulo, 1994.

HELPMAN, E. Imperfect competition and international trade: Evidence from fourteen industrial countries. Journal of The Japanese and International Economies, v. 1, n. 1, p. 62 81, 1 mar. 1987.

HESSE, M.; RODRIGUE, J. P. The transport geography of logistics and freight distribution. Journal of Transport Geography, v. 12, n. 3, p. 171-184, 2004.

HUMMELS, D. L.; SCHAUR, G. Time as a trade barrier. American Economic Review, v. 103, n. 7, p. 2935-2959, dez. 2013.

INKLAAR, R.; TIMMER, M. P. Of yeast and mushrooms: Patterns of industry-level productivity growth. German Economic Review, v. 8, n. 2, p. 174-187, 1 maio 2007. Disponível em: <https:/www.degruyter.com/view/journals/ger/8/2/article-p174.xml $>$. Acesso em: 2 out. 2020. 
ITU. Recommendation ITU-R M.2083-0 IMT Vision-Framework and overall objectives of the future development of IMT for 2020 and beyond $M$ Series Mobile, radiodetermination, amateur and related satellite services. 2015. Disponível em: $<$ http://www.itu.int/ITU-R/go/patents/en>. Acesso em: 24 set. 2020.

JORGENSON, D. W.; VU, K. M. The ICT revolution, world economic growth, and policy issues. Telecommunications Policy, v. 40, n. 5, p. 383-397, 1 maio 2016.

JUNGMITTAG, A.; WELFENS, P. J. J. Liberalization of EU telecommunications and trade: Theory, gravity equation analysis and policy implications. International Economics and Economic Policy, v. 6, n. 1, p. 23-39, 1 abr. 2009.

KABIR, M.; SALIM, R.; AL-MAWALI, N. The gravity model and trade flows: Recent developments in econometric modeling and empirical evidence. Economic Analysis and Policy, v. 56, p. 60-71, 1 dez. 2017.

LAM, P. L.; SHIU, A. Economic growth, telecommunications development and productivity growth of the telecommunications sector: Evidence around the world. Telecommunications Policy, v. 34, n. 4, p. 185-199, 1 maio 2010.

LEE, J. Network effects on international trade. Economics Letters, v. 116, n. 2, p. 199-201, 1 ago. 2012.

LIN, F. Estimating the effect of the Internet on international trade. The Journal of International Trade \& Economic Development, v. 24, n. 3, p. 409-428, 3 abr. 2015. Disponível em: <http://www.tandfonline.com/doi/full/10.1080/09638199.2014.881906>. Acesso em: 17 jan. 2021.

LIU, L.; NATH, H. Information and communications technology and trade in emerging market economies. Emerging Markets Finance and Trade, Routledge, 1 nov. 2013.

LOS, B.; TIMMER, M. P.; DE VRIES, G. J. How global are global value chains? A new approach to measure international fragmentation. Journal of Regional Science, v. 55, n. 1, p. 66-92, 2015.

MALLIDIS, I.; DEKKER, R.; VLACHOS, D. The impact of greening on supply chain design and cost: A case for a developing region. Journal of Transport Geography, v. 22, p. 118 $128,2012$.

MARTÍNEZ-ZARZOSO, I.; MÁRQUEZ-RAMOS, L. Exports and governance: Is the Middle East and North Africa region different? The World Economy, v. 42, n. 1, p. 143-174, 2 jan. 2019. Disponível em: < https://onlinelibrary.wiley.com/doi/abs/10.1111/twec.12633>. Acesso em: 25 jul. 2020.

MELITZ, J.; TOUBAL, F. Native language, spoken language, translation and trade. Journal of International Economics, v. 93, n. 2, p. 351-363, 1 jul. 2014.

NORTON, S. W. Transaction costs, telecommunications, and the microeconomics of macroeconomic growth. Economic Development \& Cultural Change, v. 41, n. 1, p. 175-196, 19 out. 1992. 
OSNAGO, A.; TAN, S. W. Disaggregating the Impact of the Internet on International Trade. Policy Research Working Papers. The World Bank, 8 ago. 2016. Disponível em: $<$ http://elibrary.worldbank.org/doi/book/10.1596/1813-9450-7785>. Acesso em: 30 set. 2020.

OVERÅ, R. Networks, distance, and trust: Telecommunications Development and changing trading practices in Ghana. World Development, v. 34, n. 7, p. 1301-1315, 1 jul. 2006.

PESSOA, E.; MARTINS, M. Revisitando a teoria do ciclo do produto. Revista de Economia Contemporânea, v. 11, n. 2, p. 307-329, ago. 2007. Disponível em: $<$ https://doi.org/10.1590/S1415-98482007000200005>. Acesso em: 25 fev. 2021.

RAVENSTEIN, E. G. The Laws of Migration. Journal of the Statistical Society of London, v. 48 , n. 2 , p. 167 , jun. 1885 .

RODRÍGUEZ-CRESPO, E; MARTÍNEZ-ZARZOSO, I. The effect of ICT on trade: Does product complexity matter? Telematics and Informatics, v. 41, p. 182-196, 1 ago. 2019.

ROS, A. J.; BANERJEE, A. Telecommunications privatization and tariff rebalancing: Evidence from Latin America. Telecommunications Policy, v. 24, n. 3, p. 233-252, 1 abr. 2000.

SALAHUDDIN, M.; GOW, J. The effects of Internet usage, financial development and trade openness on economic growth in South Africa: A time series analysis. Telematics and Informatics, v. 33, n. 4, p. 1141-1154, 1 nov. 2016.

SANTOS SILVA, J. M. C.; TENREYRO, S. The log of gravity. The Review of Economics and Statistics, v.88, n. 4, p. 641-658, nov. 2006.

SEO, H. J.; LEE, Y. S.; OH, J. H. Does ICT investment widen the growth gap? Telecommunications Policy, v. 33, n. 8, p. 422-431, 1 set. 2009.

SHIU, A.; LAM, P. L. Causal relationship between telecommunications and economic growth in China and its regions. Regional Studies, v. 42, n. 5, p. 705-718, jun. 2008. Disponível em: $<$ https://www.tandfonline.com/doi/abs/10.1080/00343400701543314>. Acesso em: 1 out. 2020 .

SILVA, O. M. Comércio Internacional e Protecionismo Agrícola. In: SANTOS, M. L.; VIEIRA, W. C. (Org.) Agricultura na virada do milênio: velhos e novos desafios. $1^{\mathrm{o}}$ ed., p. 285-302, 2000.

SOUSA, J. The currency union effect on trade is decreasing over time. Economics Letters, v. 117, n. 3, p. 917-920, 1 dez. 2012.

STEPHENSON, S. M. Cadeias globais de valor: a nova realidade do comércio internacional. PONTES - Informações e Análises sobre Comércio Sustentável, v. 11, n. 2, p. 17-21, 2015.

STIGLITZ, J. E. Freefall: America, free markets, and the sinking of the world economy. New York: WW Norton \& Company, 2010.

TADAYONI, R.; HENTEN, A.; SØRENSEN, J. Mobile communications - On standards, classifications and generations. Telecommunications Policy, v. 42, n. 3, p. 253-262, 1 abr. 2018. 
TAVASSZY, L. et al. A strategic network choice model for global container flows: Specification, estimation and application. Journal of Transport Geography, 2011.

TINBERGEN, J. Shaping the world economy: suggestions for an international economic policy. 1962. Disponível em: <https://repub.eur.nl/pub/16826/Appendices.pdf>. Acesso em: 29 set. 2020.

UNITED NATIONS. Comtrade | International Trade Statistics Database. Disponível em: $<$ https://comtrade.un.org/>. Acesso em: 28 fev. 2021.

VEMURI, V. K.; SIDDIQI, S. Impact of commercialization of the Internet on international trade: A panel study using the extended gravity model. International Trade Journal, v. 23, n. 4, p. 458-484, out. 2009.

VERNON, R. International investment and international trade in the product cycle. Quarterly Journal of Economics, v. 80, n. 2, p. 190-207, 1966.

VISSER, R. The effect of the internet on the margins of trade. Information Economics and Policy, v. 46, p. 41-54, 1 mar. 2019.

WALMSLEY, T. L. Incorporating international ownership of endowments into a global applied general equilibrium model. Economic Modelling, v. 19, n. 5, p. 679-707, 2002.

WANG, M. L.; CHOI, C. H. How information and communication technology affect international trade: a comparative analysis of BRICS countries. Information Technology for Development, v. 25, n. 3, p. 455-474, 3 jul. 2019.

WANG, Y.; LI, J. ICT's effect on trade: Perspective of comparative advantage. Economics Letters, v. 155, p. 96-99, 1 jun. 2017.

WELLENIUS, B.; STERN, P. A. Implementing reforms in the telecommunications sector: lessons from experience. World Bank, 1994.

WHAlleY, J. Why Do Countries Seek Regional Trade Agreements? NBER Working Papers: University of Chicago Press, 1 jan. 1998.

WORLD BANK. DataBank WDI. Disponível em: $<$ https://databank.worldbank.org/home.aspx>. Acesso em: 5 out. 2020.

WTO, World Trade Organization. The WTO and preferential trade agreements: From coexistence to coherence. Geneva, 2011. Disponível em: $<$ https://www.wto.org/english/res_e/booksp_e/anrep_e/world_trade_report11_e.pdf $>$. Acesso em: 5 out. 2020.

XING, Z. The impacts of Information and Communications Technology (ICT) and Ecommerce on bilateral trade flows. International Economics and Economic Policy, v. 15, n. 3, p. 565-586, 1 jul. 2018.

YADAV, N. The role of internet use on international trade: Evidence from Asian and subsaharan African enterprises. Global Economy Journal, v. 14, n. 2, p. 189-214, 1 jun. 2014. 
YOTOV, Y. V. et al. An Advanced Guide to Trade Policy Analysis: The Structural Gravity Model. WTO, 2016.

YUSHKOVA, E. Impact of ICT on trade in different technology groups: Analysis and implications. International Economics and Economic Policy, v. 11, n. 1-2, p. 165-177, 24 fev. 2014.

ZHANG, T. et al. The joint effects of information and communication technology development and intercultural miscommunication on international trade: Evidence from China and its trading partners. Industrial Marketing Management, 31 jan. 2020. 


\section{APÊNDICE A - Distância Linguística}

Como apresentado por Melitz e Toubal (2014), há a necessidade de resumir as evidências linguísticas em um índice constituído por fatores linguísticos exógenos, corrigindo assim especificidades que a questão linguística envolve, como a presença de outros idiomas dentro de um país que são utilizados para gerar facilitação de comércio, por exemplo. A elaboração do índice de distância linguística também simplifica e torna útil dentro de cenários aonde o interesse do estudo está voltado para outros lugares e há a necessidade de controlar por todos os fatores linguísticos presentes.

O índice trabalha com os seguintes controles linguísticos: COL (Língua oficial comum), CNL (Língua nativa comum) e LP2 (pontuação ASPJ de similaridade entre 200 (às vezes 100) palavras em uma lista (ou duas listas)). Sua variação acontece dentro do intervalo $0-1$ para proximidade linguística entre países. O índice é calculado privilegiando CNL, normalizando estritamente o somatório entre COL + LP2, dividindo a série pelo valor máximo encontrado na soma. De posse do somatório normalizado, multiplica-se o valor por (1 - CNL). Para finalizar o índice, é realizado a soma do valor encontrado com CNL. A equação (13) assume a seguinte forma:

PROXIMIDADE LINGUÍSTICA $=(1-\mathrm{CNL}) *\left(\frac{[\mathrm{COL}+\mathrm{LP} 2]}{\max (\mathrm{COL}+\mathrm{LP} 2)}\right)+\mathrm{CNL}$

Para chegar à distância linguística entre países, como proposto por Visser (2019), realiza a inversão da proximidade linguística calculada, subtraindo por 1:

DISTÂNCIA LINGUÍSTICA = 1 - PROXIMIDADE LINGUÍSTICA

Ou seja, dentro do intervalo 0 - 1 referente ao índice de distância linguística, quanto mais próximo de 1, maior é a distância linguística dos países envolvendo a língua oficial comum, língua nativa comum e similaridade de palavras. Para valores próximos de 0 , os países apresentam proximidade linguística no que concerne as variáveis presentes no índice, privilegiando a língua nativa comum. 